\section{INDUSTRIALIZACIÓN, DESARROLLO Y CIUDAD: TRANSFORMACIONES SOCIO-DEMOGRÁFICAS Y ESPACIALES EN LA GEOGRAFÍA SOCIAL DEL GRAN CONCEPCIÓN (1950-2010)}

Enrique Aliste Almuna²

Miguel Contreras Alonso ${ }^{3}$

Valeria Sandoval Manríquez ${ }^{4}$

\section{Resumen}

En el Gran Concepción ha habido importantes transformaciones relativas al espacio socio-demográfico y a la estructura urbana en los últimos sesenta años, vinculadas al proceso de industrialización sustitutiva de importaciones y a la posterior integración de la economía nacional al mercado globalizado. En este artículo se analizaron dichas transformaciones mediante indicadores socioeducacionales, etarios, de empleo en industria y en servicios, buscando verificar si su comportamiento espacial se asociaba con los procesos mencionados, poniéndolos en perspectiva frente a la noción de progreso y desarrollo. Los resultados muestran una temprana concentración del empleo en

\section{INDUSTRIALIZATION, DEVELOPMENT AND CITY: SOCIODEMOGRAPHIC AND SPATIALTRANSFORMATIONS WITHIN THE SOCIAL GEOGRAPHY OF GREATER CONCEPCIÓN (1950-2010) ${ }^{1}$}

Enrique Aliste Almuna²

Miguel Contreras Alonso ${ }^{3}$

Valeria Sandoval Manríquez ${ }^{4}$

\begin{abstract}
There have been important transformations regarding the sociodemographic and urban structure in Greater Concepción over the last sixty years; these changes have been related to the import-substitution industrialization and the consequent integration of the national economy within the globalized market. This paper analyzes these transformations by using socio-educational, age and employment in industry and services indicators so as to verify if the spatial behavior was linked to these processes, putting them in perspective against the notion of progress and development. The results show an early concentration of employment in industry in the
\end{abstract}


industria en la conurbación. La estructura socioeducacional mantuvo a los grupos altos en el centro de Concepción, pero ha tendido recientemente a una localización más periférica, acorde con los mecanismos de metropolización y liberalización del mercado de suelo. Se presentan dos momentos de la ciudad: uno que responde a la idea de progreso y otro que recoge la noción de desarrollo, ambas discutidas en torno a la geografía social de la ciudad.

\section{PALABRAS CLAVE: CAMBIO DEMOGRÁFICO - ESTRUCTURA URBANA -GEOGRAFÍA SOCIAL - GEOGRAFÍA URBANA.}

Fecha de recepción: 14.12.11

Fecha de aceptación: 12.08.12

1 Proyecto FONDECYT 1090248: “Huellas y dinámicas territoriales: imaginarios del desarrollo y prácticas de transformación del ambiente en el Gran Concepción".

2 Chile. Licenciado en Geografía, Escuela de Geografía, Facultad de Arquitectura y Urbanismo, Universidad de Chile; Magíster en Gestión y Planificación Ambiental de la Universidad de Chile; Dr. (C) Estudios sobre el Desarrollo (École des Hautes Études en Sciences Sociales -EHESS- Paris, Francia). Docente del Departamento de Geografía de la Facultad de Arquitectura y Urbanismo de la Universidad de Chile. Correo electrónico: ealiste@ uchilefau.cl.

3 Chile. Licenciado en Geografía de la Universidad de Chile. Magíster en Geografía, mención Organización Urbano-Regional. de la Universidad de Chile. Docente del Departamento de Geografía de la Facultad de Arquitectura y Urbanismo de la Universidad de Chile. Correo electrónico: mcalonso@uchilefau.cl.

4 Geógrafa Universidad de Chile. Correo electrónico: valeriasandoval@gmail.com. peri-urban area. The socio-educational structure retained high income groups in the downtown area of Concepción, but it has recently showed a more peripherallocalization, in line with metropolization mechanisms and the liberalization of the land market. This article presents two moments of the city: one belonging to the idea of progress and the other is the notion of development; both concepts are discussed by taking the social geography of the city as a basis.

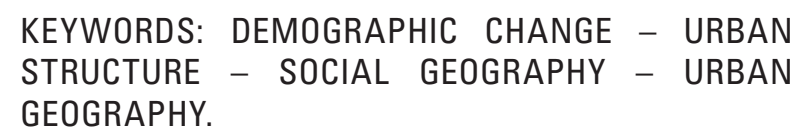

Received: 14.12.11

Accepted: 12.08.12

1 FONDECYT Project 1090248 "Footprints and territorial dynamics: imaginaries of development and transformation practices of environment in Greater Concepción".

2 Chile. BA in Geography, Escuela de Geografía, Facultad de Arquitectura y Urbanismo, Universidad de Chile; MA in Management and Environmental Planning, Universidad de Chile; Ph.D.(C) Studies on Development, Ecole des Hautes Études en Sciences Sociales -EHESS- Paris, France. Professor, Departamento de Geografía, Facultad de Arquitectura y Urbanismo, Universidad de Chile.Email: ealiste@uchilefau.cl.

3 Chile. BA in Geography, Universidad de Chile. MA in Geography, specializing in Urban-Regional Planning, Universidad de Chile. Professor, Departamento de Geografía, Facultad de Arquitectura y Urbanismo, Universidad de Chile. Email: mcalonso@uchilefau.cl.

4 Geographer, Universidad de Chile. Email: valeriasandoval@ gmail.com. 


\section{Introducción}

El Gran Concepción corresponde a una conurbación que comprende actualmente a las comunas de Concepción, Talcahuano, Penco, San Pedro de la Paz, Chiguayante y Hualpén. Se encuentra en el centro sur de Chile, en la región del Biobío, en la zona costera ubicada entre los $36^{\circ} 43^{\prime}$ y los $36^{\circ} 50^{\prime}$ de latitud sur aproximadamente.

Las comunas que conforman el Gran Concepción representan un área total de aproximadamente 551,4 Km², con una población que para el año 2002 alcanzó un total de 622.364 habitantes y 168.675 viviendas ${ }^{5}$. Dichas comunas poseen el más alto nivel de urbanización de la región del Biobío ${ }^{6}$. Según los datos del Gobierno Regional, la evolución demográfica de estas comunas muestra crecimientos muy significativos, con una tendencia que debería mantenerse en los próximos años.

Las transformaciones en el territorio del Gran Concepción durante la segunda mitad del siglo XX se pueden caracterizar de diferentes maneras. Hacerlo en su dimensión sociodemográfica permite avanzar en la geografía social de la ciudad en tanto podemos interpretar que dichos cambios, derivados de un proceso de industrialización originado en el desarrollismo de los años '50, al mismo

$5 \quad$ INE. 2007.

6 INE. 2002.

\section{Introduction}

Greater Concepcion is a conurbation that includes the municipalities of Concepción, Talcahuano, Penco, San Pedro de la Paz, Chiguayante and Hualpén. Greater Concepción is located in central/southern Chile, in the Bíobio region, latitude 36" 43' to 36" 50' south.

The municipalities belonging to Greater Concepción represent a total area of 551.4 $\mathrm{km}^{2}$ with a population of 622,364 inhabitants and 168,675 households in 20025. These townships have the higher urbanization rate of the Biobio region ${ }^{6}$. According to data retrieved from the Regional Government, the demographic evolution of these municipalities shows an important increase, with a tendency that should continue in the future. However, the transformations in Greater Concepcion over the second half of the XX century can be characterized in different ways. The sociodemographic analysis offers a deeper insight into the social demography of the city as these changes, derived from the industrialization process that began in the fifties $-a$ process that brought along the organization of the

5 INE. 2007.

INE. 2002. 
FIGURA 1: ÁREA DE ESTUDIO.

FIGURE 1: AREA OF RESEARCH

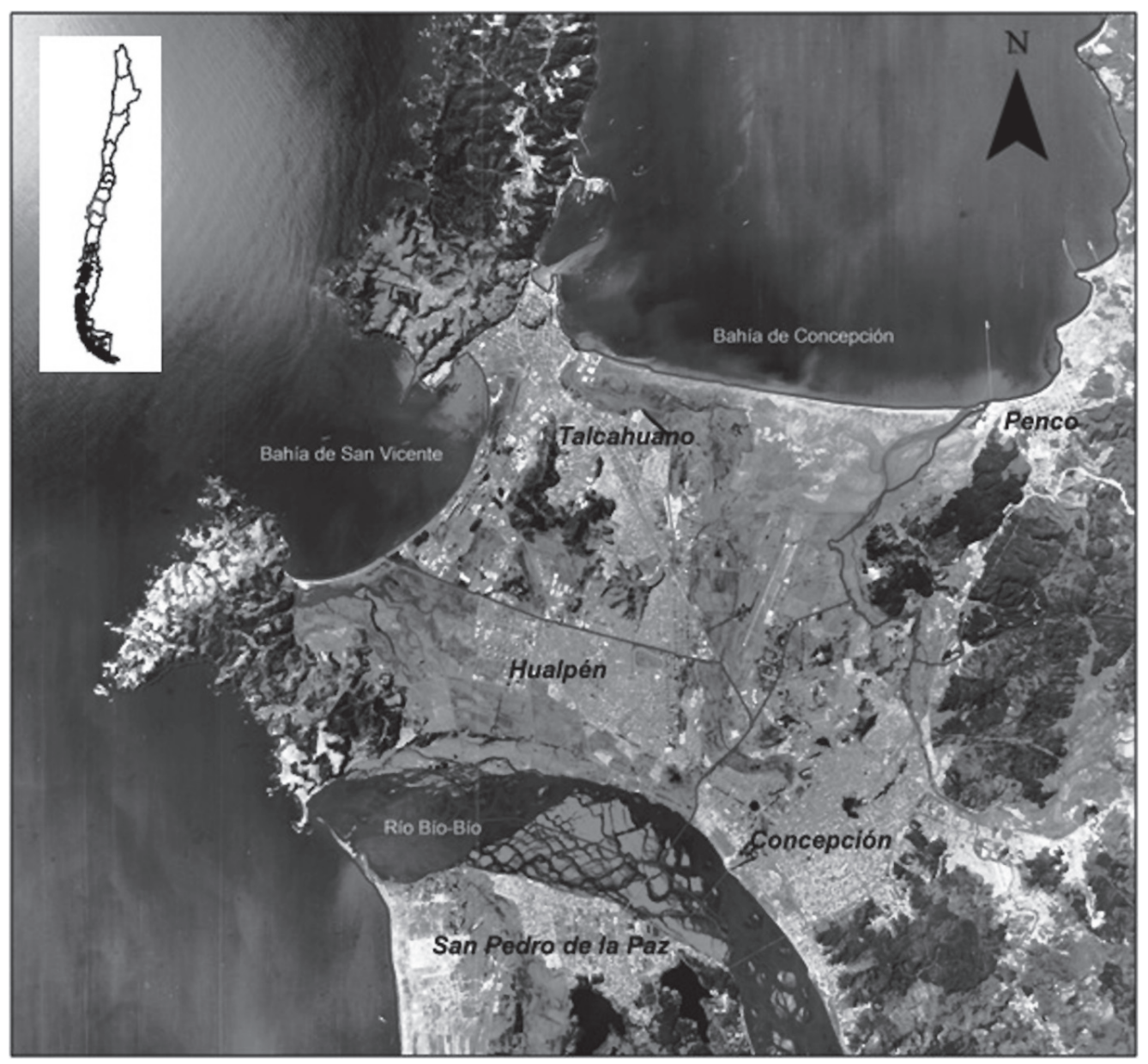

Fuente: Elaboración propia en base a cartografía 1:250.000 IGM y fotointerpretación 
tiempo que acompañan la conformación de la ciudad, le va otorgando el carácter y sentido que hoy posee en tanto "ciudad industrial". Sin embargo, el análisis que aquí se realiza, muestra que el sello de su carácter industrial ya no radica en el peso que la actividad posee si se mira el perfil de su población en la actualidad.

Exploradas algunas variables sociodemográficas en el tiempo, se puede ver que este carácter propio de la ciudad industrial ha cambiado y ya no posee la relevancia que sí tenía en los años previos a la década del '90. No obstante, embargo, la imagen de la ciudad industrial persiste hasta el día de hoy.

Es sobre esta situación que el presente artículo busca avanzar; se espera discutir una perspectiva de análisis centrada en las formas mediante las cuales se articula la geografía social de una ciudad, mirando la industria y su rol de incidencia en ella. Por lo mismo, se avanza también en ofrecer una mirada a las representaciones de la ciudad que se sustentan más en el peso de una tradición reciente que en la realidad actual.

Algunos pasos previos para esta exploración, exigen comprender los procesos que demográficamente van articulando el espacio social urbano, razón por la que es relevante comprenderlos en el tiempo y el espacio de manera indisoluble ${ }^{7}$. Tiempo y espacio como un todo articulado de una

7 Soja, E. 1999 y Di Méo, G. 1998 city-, give this area the character and sense of an "industrial city." However, the analysis of the population of Greater Concepcion shows that this feature is no longer represented by the relevance of industrial activity.

After studying sociodemographic variables it is possible to see that this industrial character has changed and is not as important as it was prior to the 90s. Nevertheless, the image of industrial city is still present today. This article explores this situation, it is expected to discuss on an analysis perspective focused on the ways the social geography of a city gravitates towards industry. The extent to which this social geography influences the city is also discussed. Likewise, this contribution offers a view of the representations of the city that rely more on recent tradition than on current reality.

Some of the previous steps of this research are compulsory in order to have a grasp of the processes that demographically shape the urban social space; this is why it is important to understand these transformations in space and time as an indissoluble unit ${ }^{7}$. Space and time are seen as a whole associated with a history contained within its geography; for this reason

7 Soja, E. 1999; Di Méo, G. 1998. 
historia contenida en su geografía, exige de una mirada que intente concebir al territorio como resultado de este proceso ${ }^{8}$.

\section{El Gran Concepción como ciudad industrial: procesos generales en su configuración urbana actual ¿Por qué la mirada sociodemográfica?}

El paulatino incremento de las actividades industriales y de servicios ${ }^{9}$ es de gran relevancia para el Gran Concepción. En efecto, esta entidad urbana, que es una de las tres grandes metrópolis del país, se ha visto influida por diversas políticas y estrategias de desarrollo implementadas desde mediados del siglo pasado, llegando a conformar un importante polo industrial y así, un sello y carácter estrechamente asociado a la industria ${ }^{10}$. Dicho carácter fue impulsado por la Corporación de Fomento de la Producción (CORFO) mediante la puesta en marcha de proyectos clave para la economía nacional y regional como la electricidad, el petróleo, pero sobre todo el acero ${ }^{11}$. La Siderúrgica Huachipato de la Compañía de Aceros del Pacífico (CAP), inaugurada

Aliste, E. 2011

Azócar, G., Sanhueza, R. y Henríquez, C., 2003.

Aliste, E. y Almendras, A. 2010.

Hernández, H. 1983. the territory should be regarded as a result of this process ${ }^{8}$

\section{Greater Concepción as an industrial city: general processes of current urban structure. Why the sociodemographic approach?}

The gradual growth of industrial and services activities ${ }^{9}$ is essential for Greater Concepción. In effect, this urban entity, one of the three major Chilean cities, has been influenced by different development policies and strategies implemented back in the fifties, as a result, Greater Concepción became an important industrial center and acquired a seal and character closely linked to industry ${ }^{10}$. Such a character was promoted by the Production Development Corporation (CORFO) through the implementation of key projects in favor of the national and local economy such as the production of electricity, oil and most especially, steel $^{11}$. The Huachipato steel complex, owned by

Aliste, E. 2011.

Azócar, G., Sanhueza, R. y Henríquez, C., 2003

Aliste, E. and Almendras, A.2010.

Hernández, H. 1983. 
en 1950, se considera uno de los hitos más importantes de la historia urbana de la ciudad y fue emblema de la política de industrialización y sustitución de importaciones, que entre otras inversiones incluyó la planta refinadora de petróleo de ENAP y cuatro plantas petroquímicas en la bahía de San Vicente.

Las políticas de la industrialización y sustitución de importaciones (ISI) implicaban una participación muy activa por parte del Estado en la economía y la producción nacional, fomentando la creación de industrias semiestatales o estatales protegidas aduaneramente frente a la competencia extranje$\mathrm{ra}^{12}$. Con ello se buscaba combinar el proteccionismo comercial de las manufacturas y la integración comercial de América Latina, además de coordinar la especialización productiva y exportadora de los países de la región; a la vez, se buscaba compensar el tamaño de los mercados internos, que se hacían insuficientes, con los mercados regionales ${ }^{13}$. En dicho período se pensó a Concepción y Talcahuano como un gran polo de desarrollo industrial basado en atributos espaciales relevantes como la presencia de dos importantes y abrigadas bahías aptas para la actividad portuaria, un gran río que, además de navegable, ofrecía un importante potencial hidroeléctrico, cercanía a los grandes yacimientos de cobre del Golfo de Arauco, existencia de una importante red de caminos y ferrovías, entre otras

12 Góngora, M. 1981.

13 Turmo, J. y Morales G. 2007. the Pacific Steel Company (CAP), was launched in 1950 and is one of the most important milestones in the urban history of the city and the symbol of the import substitution and industrialization policy, which also included the construction of the National Oil Company (ENAP) oil refinery and four petrochemical complexes in the Bay of San Vicente.

The import-substitution industrialization policies (ISI) implied an active participation of the State in the economy and national production, promoting the creation of semi-state or state-owned industries protected against foreign competitors ${ }^{12}$. The idea was to combine the commercial protectionism of manufacturing plants and the economic integration of Latin America, apart from coordinating the productive and export specialization of Latin American countries; in addition, the small size of internal markets was compensated in relation to regional markets ${ }^{13}$. During this period, Concepcion and Talcahuano were thought to be an important industrial development center due to relevant spatial features such as the presence of two important and protected bays suitable for port activity; a large river which, apart from being

12 Góngora, M. 1981

13 Turmo, J. and Morales G. 2007. 
virtudes ${ }^{14}$, sin considerar, sin embargo, las frágiles condiciones naturales en que se insertaba ${ }^{15}$.

Así, la instalación de las industrias favorece una rápida expansión del área urbana, articulando hoy una importante área metropolitana con incrementos porcentuales de su superficie que incluso fueron mayores a los experimentados por Santiago entre las décadas de 1950 y 197016. Ello trae consigo dificultades y escasez de sitios urbanizables, por lo que se ve obligada a crecer sobre los espacios comunales cada vez más alejados (San Pedro, Penco y Chiguayante $)^{17}$. Estos sectores, paulatinamente se convierten en ciudades-dormitorios que exhiben un crecimiento demográfico superior al crecimiento de sus bases económicas ${ }^{18}$, conformando un área urbana integrada funcionalmente, aunque espacialmente desarticulada. Como consecuencia de este crecimiento existen comportamientos y dinámicas socio-espaciales relevantes que se manifiestan hasta hoy, asociados a cambios en la distribución interna de la población, y a la presencia de diferencias sociales y de nivel de vida.

De esta forma, poner el acento en cómo sociodemográficamente se va articulando esta ciudad industrial a la luz de las nociones de desarrollo

14 Almeyda Arroyo, E. 1955.

15 llabaca, P. 1995.

16 Aliste, E. y Almendras, A. 2010.

17 Franck, S. y Pérez, L. 2009.

18 Hernández, H. 1983. suitable for navigation, it offered an important hydroelectric potential and closeness to the large copper deposits located in the Arauco Gulf; as well as the presence of an important network of roads and railway lines, among others ${ }^{14}$; however, the fragile natural conditions of this area were not taken into consideration ${ }^{15}$.

In this way, the construction of industries boosted the expansion of the urban area, giving shape to an important metropolitan area with a percentage increase in surface higher to that experienced by Santiago between 1950 and $1970^{16}$. This situation entailed difficulties and shortage of land for development, as a consequence, the city saw itself forced to grow over distant locations (San Pedro, Penco and Chiguayante $)^{17}$. These areas became dormitory towns with a demographic growth that exceeded economic growth ${ }^{18}$, creating an urban area functionally integrated but spatially disjointed. As a result, there are behaviors and sociospatial dynamics that remain until today; these factors have their roots in the changes within the internal distribution of the population 
que las avalan, y acompañar al mismo tiempo el proceso con miras a sugerir las implicancias que éste posee en la conformación del territorio que hoy caracteriza a este núcleo urbano como ciudad industrial, ayuda desde nuestra perspectiva la posibilidad a avanzar en una geografía social de la ciudad capaz de orientar definiciones y acciones sobre su planificación.

Cabe destacar que durante el período de análisis (1950-2002), el área ha cambiado varias veces sus límites político-administrativos, lo que en general, tiende a dificultar el manejo de los datos demográficos y censales. Por ello, la investigación tuvo que realizar ciertos ajustes, incorporando para un período inicial a la comuna de Coronel, que entre 1950 y 1970 llegaba hasta el río Biobío (territorio actualmente perteneciente a la comuna de San Pedro de la Paz).

En el presente análisis, se identifican algunos hitos históricos que pueden haber afectado la estructura urbana y se busca su manifestación en una serie de variables, tales como empleo en industria y servicios, estructura etaria y nivel socio-educacional de la población, entre otras. Con este fin, se planteó una investigación que comprendiera dos ámbitos: por un lado ver la evolución de los indicadores, basados en la mayor cantidad de datos censales posible; y por otro, analizar los eventos que marcaron la estructura urbana de la ciudad, mediante revisión bibliográfica y entrevistas a informantes clave.

ARTÍCULO: Industrialización, desarrollo y ciudad: transformaciones socio-demográficas y espaciales en la geografía social del Gran Concepción (1950-2010)

Enrique Aliste Almuna, Miguel Contreras Alonso y Valeria Sandoval Manríquez and the presence of social and quality of life differences.

In this way, stressing how this industrial city gets socio-demographically articulated according to development notions, and following this process so as to suggest implications regarding the industrial nature of this urban area, is useful to get a deeper insight into a social geography that guides definitions and measures related to its own planning.

It is worth noting that during the analyzed period (1950-202) this area changed its political administrative limits several times, so it is difficult to manage demographic data and census databases information. This is why this research made some adjustments such as including Coronel, which between 1950 and 1970 reached the Biobio River (a territory that today is part of San Pedro de la Paz.)

This research identifies historic moments that influenced the urban structure of Greater Concepción, as well as the effects these events had on variables such as employment in industries and services, age structure and the socio-educational level of the population, among others. In this sense, this research included two relevant areas: the first one is the evolution of 


\section{El Gran Concepción, su estructura urbana y la ciudad metropolitana. Mirar la ciudad en el tiempo y el espacio}

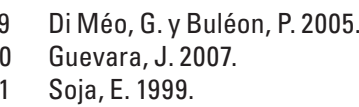

\begin{abstract}
Entender los cambios en la estructura urbana del Gran Concepción, requiere de una aproximación a los procesos históricos que acompañan la configuración del territorio. Por ello, es preciso concordar en comprender las ciudades como manifestaciones tanto físicas como sociales, las cuales existen bajo una permanente fusión que van compartiendo e imbricando sus planos espaciales y temporales ${ }^{19}$; por consiguiente, vislumbrar cómo ha influenciado esta fundamental unión entre procesos históricos y su espacio llevaría a conocer cómo se ha configurado la estructura urbana ${ }^{20}$. Tal como lo plantea Edward Soja, la predominancia durante el siglo XX de la dimensión temporal y la historia por sobre otras formas de concebir la naturaleza de los fenómenos sociales, relegando el rol del espacio a un plano secundario o bien como dimensión estática, ha impedido una aproximación más certera a la complejidad de los hechos que caracterizan a los procesos sociales ${ }^{21}$. Comprender la relación entre los procesos históricos y
\end{abstract}

(1)

indicators, which are based on the highest possible volume of available data; and the second one is the study of the events that left an imprint on the urban structure of the city through bibliographic analysis and interviews to key respondents.

\section{Greater Concepcion, urban structure and the metropolitan city. Observing the city in space and time}

Understanding the changes within the urban structure of Greater Concepción requires comprehending the historical processes that gave shape to this territory. This is why cities should be understood as physical and social manifestations that exist under permanent fusion, overlapping spatial and temporal layers $^{19}$; therefore, envisaging the influence of the union between historical processes and space would enable figuring out the configuration of the urban structure ${ }^{20}$. According to Edward Soja, the preeminence of temporal dimension and history over other ways of conceiving the

19 Di Méo, G. and Buléon, P. 2005.

20 Guevara, J. 2007. 
su correlato espacial implica entonces aceptar mirar cómo el tiempo deja sus huellas en el espacio o bien, cómo el espacio también va marcando el devenir de los procesos en el tiempo ${ }^{22}$, contribuyendo así a construir una noción dinámica de territorio $^{23}$. De esta forma, inevitablemente se llega a la noción de una "geohistoria" braudeliana, que sostiene la necesidad de ver el espacio y el tiempo como unicidad para comprender el conjunto de fenómenos sociales que se viven en un espacio determinado ${ }^{24}$.

Se puede decir en consecuencia, que la incorporación de la relación entre geografía e historia contiene una funcionalidad que es clave para la comprensión de procesos como el que interesa en este trabajo, puesto que permite conocer la huella del pasado en el presente y de esta manera, el modo en que el presente exige ser observado. La ciudad entonces, vista como proceso y no como objeto, presenta desafíos importantes en el plano no sólo conceptual ni metodológico, sino también y por sobre todo, en el plano de su interpretación y búsqueda de comprensión global.

En virtud de lo anterior, el Gran Concepción merece mirarse como aquella cuidad que transita por una particularidad que es la de vivir y

\footnotetext{
22 Aliste, E. 2011

23 Hiernaux, D. y Lindón, A. 2006

24 Braudel, F. 1997.
}

ARTÍCULO: Industrialización, desarrollo y ciudad: transformaciones socio-demográficas y espaciales en la geografía social del Gran Concepción (1950-2010)

Enrique Aliste Almuna, Miguel Contreras Alonso y Valeria Sandoval Manríquez nature of social phenomena during the 20th century, apart from relegating the role of space to a secondary role or to a aesthetic dimension, it has prevented a more accurate approximation to the complexity of the elements that characterize social processes ${ }^{21}$. Understanding the relationship between historical processes and its spatial correlate implies accepting both the traces left by time in relation to space and the influence of space over time $e^{22}$, thus creating a dynamic notion of territory ${ }^{23}$. In this way, there is inevitably the braudelian "geohistory" concept, in which space and time should be seen as a whole unit to comprehend social phenomena within a given place ${ }^{24}$.

Therefore, it is possible to say that the relationship between geography and history is essential to understand processes such as the one that is being analyzed in this paper, as it allows knowing the traces of the past and how present should be studied. Then, the city is seen as a process and not as an object; it presents important challenges not only at conceptual or methodological level, but also at interpretative and global understanding level.

21 Soja, E. 1999

22 Aliste, E. 2011.

23 Hiernaux, D. and Lindón, A. 2006

24 Braudel, F. 1997. 
responder a una noción de desarrollo que se tensiona con su historia vista en su geografía y, en el caso del presente trabajo, viendo como acoge y muta desde su estructura sociodemográfica en el contexto urbano, que es una de las tantas formas de observarla.

El fenómeno urbano en el mundo, por su parte, ha seguido diversos patrones funcionales y territoriales a lo largo de la historia, reflejando el modo de vivir y de organizarse de cada sociedad. Cuando se habla del espacio urbano, los procesos de transformación se presentan como el reflejo de los cambios en las estructuras productivas, organizacionales y culturales de una sociedad. En virtud de ello, mirar los cambios de la ciudad debe entenderse como la respuesta de la sociedad a través del espacio o bien, entender a la ciudad como una lectura geográfica de la sociedad ${ }^{25}$. Los cambios en la estructura sociodemográfica del Gran Concepción, por lo tanto, más allá de mirarlo en un sentido valorativo (cambios para bien o para mal), deben a nuestro juicio entenderse como el proceso a través del cual se puede avanzar hacia la comprensión de la ciudad.

Otro punto importante de considerar a la hora de analizar las transformaciones existentes en una ciudad como el Gran Concepción es el paradigma de la globalización, puesto que existe

25 Di Méo, G. y Buléon P. 2005.
Greater Concepción should be regarded as a city that lives and responds to a notion development that clashes with the history contained within its geography and, in the case of this paper, as a city that welcomes and changes from its sociodemographic structure in an urban context.

The urban phenomenon has followed different functional and territorial patterns, reflecting the ways of life and organization of societies around the world. When speaking about urban space, the transformation processes are the illustration of changes within productive, organizational and cultural structures of society. In this sense, the changes of the city should be understood as the response of society through space, in other words, it is a geographic picture of society ${ }^{25}$. More than being observed from a value-based perspective (for better or for worse), the changes within the sociodemographic structure of Greater Concepción should be seen as the process through which it is possible to progress towards the understanding of the city.

Another important aspect to consider when it comes to analyzing existing transformations in Greater Concepción is the globalization paradigm, as there is a consensus that cities

25 Di Méo, G. and Buléon, P. 2005 
un consenso que afirma que las ciudades están experimentando cambios profundos por transformaciones derivadas de los procesos de globalización económica, cultural, política, tecnológica, etc. ${ }^{26}$ Hoy, todas las ciudades son tocadas por este proceso mundial y su involucramiento se expresa en la influencia y alcances de este paradigma ${ }^{27}$. Esta globalización, junto con los avances tecnológicos en las telecomunicaciones, en la generalización de la movilidad mediante el uso del automóvil, de cambiar drásticamente las relaciones de producción y consumo, entre otros efectos, han alterado la utilización del territorio por distintos grupos sociales, lo que incluso ha llevado a algunos autores a hablar de una nueva relación sociedad-territorio ${ }^{28}$.

Finalmente, para realizar el análisis de una ciudad metropolitana como el Gran Concepción, hay que reconocer la importancia de los modelos teóricos planteados dentro de la geografía urbana para describir la estructura interna de las grandes ciudades, puesto que sirven para acumular y relacionar el conocimiento acerca de diferentes aspectos de la realidad, lo que permite superar la complejidad de los fenómenos que se dan en el territorio por medio de una representación más sencilla. En tal sentido, trabajos como el realizado por Pérez e Hidalgo ${ }^{29}$

26 Pérez, Ly Salinas, E. 2007.

27 Mattos, C. de, 2002.

28 Font, A. 1997.

29 Pérez, L. e Hidalgo, R. 2010. are experiencing deep changes as a result of transformations triggered by economic, cultural, political and technological globalization processes ${ }^{26}$. Today, every city is affected by this global process and their involvement is reflected on the influence and scope of this paradigm ${ }^{27}$. Globalization, along technological breakthroughs in communications, generalization of mobility through the use of vehicles, and drastic changes in production and consumption, among others, has altered the use of land, thus affecting different social groups; some authors have even mentioned a new relation society-territory ${ }^{28}$.

Finally, before analyzing a metropolitan city such as Greater Concepción, it is worth mentioning the importance of theoretical models proposed within urban geography to describe the internal structure of large cities, as they are useful to gather and relate knowledge about different aspects of reality, thus overcoming the difficulty created by different phenomena. In this sense, research carried out by Pérez and Hidalgo ${ }^{29}$ is of great relevance since it generates a wide overview of the process occurring

26 Pérez, L and Salinas, E. 2007.

27 Mattos, C. de, 2002

28 Font, A. 1997.

29 Pérez, L. and Hidalgo, R. 2010. 
son de gran trascendencia, en tanto han permitido generar una amplia mirada al proceso del Gran Concepción destacando sus aspectos urbanísticos, arquitectónicos, ambientales e históricos referidos a la ciudad, resaltando entre otros aspectos la relevancia de sus procesos socio-espaciales, de gestión de áreas urbanas, de ocupación y de proyecciones y desafíos.

\section{Criterios metodológicos para el análisis}

Con el fin de abarcar el período de análisis, se consideraron inicialmente los Censos de Población y Vivienda realizados entre 1940 y 2002. La metodología tuvo que ser dividida en dos grandes etapas que permitiesen el análisis de datos censales, puesto que la información que entregan no es igual en su nivel de resolución ni en los tipos de variables recopiladas en cada censo.

\section{PRIMER PERÍODO (1940-1970)}

La escala espacial de análisis es comunal, nivel mínimo disponible en los censos del período. La estructura de los censos es más general y menos desarrollada, por lo que los datos y variables para ser analizados son menos detallados. Cabe señalar que los datos del censo de 1960 no existen a nivel comunal (sólo a nivel provincial), por lo que in Greater Concepción, highlighting urban, architectural, environmental and historical aspects and the relevance of socio-spatial, management of urban areas and employment processes, as well as projections and challenges.

\section{Methodological Criteria Used in the Analysis}

In order to cover the analyzed period, this paper initially used data retrieved from the censuses carried out between 1940 and 2002. In order to analyze this information, the methodology was divided into two large stages since there are different censuses and different resolution levels and variables.

\section{FIRST PERIOD (1940-1970)}

The spatial scale of the analysis is at community level, the lowest unit available in that period. The structure of these censuses is more general and less developed, the analyzed information and variables are less detailed. It is worth noting that the 1960 census does not provide community level data (only provincial data), this sample was therefore eliminated from the analysis. Information from the municipalities 
se excluyeron del análisis. Para considerar los actuales territorios del Gran Concepción, se tuvo que reunir la información de las comunas de Concepción, Penco, Talcahuano y Coronel de la época. La inclusión de la comuna de Coronel dentro de esta etapa de la investigación, se explica únicamente porque en estos años la administración del territorio, que hoy es la Comuna de San Pedro de la Paz, se encontraba bajo su administración. Los antecedentes para este período consideraron las siguientes variables comunes:

- Porcentaje de población con estudios universitarios, para identificar grupos de alto nivel socio-educacional: censos de 1952 y 1970.

- Porcentaje de población comunal empleada en actividades relacionadas con la industria: censos de 1940, 1952 y 1970.

- Porcentaje de población empleada en actividades ligadas a los servicios: censos de 1940, 1952 y 1970.

- Porcentaje de población mayor de 65 años, para ver el nivel de envejecimiento demográfico: censos de 1940, 1952 y 1970.

\section{SEGUNDO PERÍODO (1982-2002):}

Para este período se utilizó el nivel de distrito censal, pues a partir de 1982 existen datos desagregados a este nivel intracomunal. Las variables permitieron el desarrollo de algunos indicadores of Concepción, Penco, Talcahuano and Coronel dating back to the analyzed period was gathered in order to cover the current surface of Greater Concepción. The inclusion of Coronel is explained because during that period, the administration of the territory, which today is known as San Pedro de la Paz, was under its jurisdiction. Background of this period included the following common variables:

- Percentage of the population with undergraduate studies; intended to identify groups of high socio-educational level: 1952 and 1970 censuses.

- Percentage of the population engaged in activities related to industry: 1940, 1952 and 1970 censuses.

- Percentage of the population engaged in activities related to services: 1940, 1952 and 1970 censuses.

- Percentage of the population older than 65 years; intended to observe demographic ageing: 1940, 1952 and 1970 censuses.

\section{SECOND PERIOD (1982-2002)}

The census district level was used to analyze this period, intracommunal disaggregated data 
de mayor complejidad para los aspectos socio-educacionales, de manera tal que se consideraron las variables detalladas en la Tabla 1.

\section{PERIODIZACIÓN HISTÓRICA E IDENTIFICACIÓN DE HECHOS URBANOS RELEVANTES}

Se identifican dos grandes períodos iniciales de análisis: el de industrialización sustitutiva de importaciones (ISI) y el de apertura al mercado externo, donde se revisó bibliografía sobre la historia urbana y económica del Gran Concepción. Relevantes fueron los antecedentes entregados por estudios históricos ${ }^{30}$, geográficos ${ }^{31}$ y urbanos ${ }^{32}$.

En ellos se identificaron elementos tales como instalación de industrias, desarrollo de grandes proyectos inmobiliarios o conjuntos de viviendas, construcción de obras de infraestructura y equipamiento relevantes y definición de políticas económicas y productivas. El objetivo era identificar sucesos históricos que definieran intervenciones con efectos significativos sobre el espacio urbano.

30 Ver los aportes de Hernández, H. 1983; Pacheco, A. 1997; Mazzei, L. y Pacheco, A. 1985, entre otros.

31 Ver los aportes de Almendras, A. 2009; Aliste, E. y Almendras, A. 2010; Smith, P. y Romero, H. 2009; Mardones, M. y Vidal, C. 2001; Rojas, C., García López, M, Muñiz, I. 2009, entre muchos otros.

32 Ver los aportes de Pérez, L.y Salinas, E. 2007; Baeriswyl, S. 2007; Núñez, F. 2007

36 revista invi ํo 75 / Agosto 2012 / Volumen No 27: 21-71 is available from 1982 onwards. The resulting variables allowed the development of more complex indicators regarding socio-educational aspects, in such a way that the variables were considered, as Table 1 shows.

\section{HISTORICAL PERIODIZATION AND IDENTIFICATION OF RELEVANT URBAN EVENTS}

There are two large initial periods: the importsubstitution industrialization (ISI) and the opening up to the external market; bibliography regarding the urban and economic history of Greater Concepción was consulted. Data retrieved from historical ${ }^{30}$, geographic ${ }^{31}$ and urban $^{32}$ research was of great importance.

The consultation of literature allowed the identification of elements such as the establishment of industries, development of large housing projects, construction of infrastructure and amenities and definition of economic and

30 See the contributions of Hernández, H. 1983; Pacheco, A. 1997; Mazzei, L. and Pacheco, A. 1985, among others.

31 See the contributions of Almendras, A. 2009; Aliste, E. and Almendras, A. 2010; Smith, P. and Romero, H. 2009; Mardones, M. and Vidal, C.2001; Rojas, C., García López, M, Muñiz, I. 2009, among others.

32 See the contributions of Pérez, L. and Salinas, E. 2007; Baeriswyl, S. 2007; Núñez, F. 2007. 
TABLA 1. RESUMEN DE VARIABLES UTILIZADAS PARA LA CONFECCIÓN DE INDICADORES EN LA ETAPA 1982- 2002.

\begin{tabular}{|c|c|c|}
\hline Indicador & Variables & Variables desagregadas \\
\hline \multirow{6}{*}{$\begin{array}{l}\text { Socio-edu- } \\
\text { cacional }\end{array}$} & \multirow{3}{*}{ Ocupación del jefe de hogar } & $\begin{array}{l}\text { Porcentaje de personas miembros del poder ejecutivo, legislativo, } \\
\text { judicial y gerencias de empresas }\end{array}$ \\
\hline & & Porcentaje de profesores, científicos e intelectuales \\
\hline & & Porcentaje de técnicos y profesionales de nivel medio \\
\hline & \multirow{2}{*}{ Nivel de instrucción } & Porcentaje de personas egresadas de instituto profesional \\
\hline & & Porcentaje de personas con educación universitaria \\
\hline & Estudios universitarios completos & $\begin{array}{l}\text { Porcentaje de personas con más de } 5 \text { años de estudios } \\
\text { universitarios }\end{array}$ \\
\hline Servicios & $\begin{array}{l}\text { Trabajadores relacionados con los } \\
\text { servicios }\end{array}$ & $\begin{array}{l}\text { Porcentaje de personas ocupadas en actividades ligadas a los } \\
\text { servicios }\end{array}$ \\
\hline Industria & $\begin{array}{l}\text { Trabajadores relacionados con la } \\
\text { Industria }\end{array}$ & Porcentaje de personas ocupadas en actividades industriales \\
\hline
\end{tabular}

Fuente: Elaboración propia.

\section{TABLE 1. SUMMARY OF VARIABLES USED FOR THE DESIGN OF INDICATORS. SECOND PERIOD 1982-2002}

\begin{tabular}{|c|c|c|}
\hline Indicator & Variables & Disaggregated Variables \\
\hline \multirow{6}{*}{$\begin{array}{l}\text { Socio-edu- } \\
\text { cational }\end{array}$} & \multirow{3}{*}{ Occupation of the head of household } & $\begin{array}{l}\text { Percentage of people engaged in executive, legislative and judi- } \\
\text { cial power and board directory of companies }\end{array}$ \\
\hline & & Percentage of professors, scientists and scholars \\
\hline & & Percentage of middle level technicians and professionals \\
\hline & \multirow{2}{*}{ Instruction level } & Percentage of people graduated from professional education \\
\hline & & Percentage of people with undergraduate studies \\
\hline & Completed undergraduate studies & $\begin{array}{l}\text { Percentage of people with more than } 5 \text { years of undergraduate } \\
\text { studies }\end{array}$ \\
\hline Services & Workers engaged in services & Percentage of people engaged in services activities \\
\hline Industry & Workers engaged in industry & Percentage of people engaged in industrial activities \\
\hline
\end{tabular}

Source: Authors' Elaboration 


\section{Resultados}

\section{LA CIUDAD DEL PROGRESO: INICIO DE LA ETAPA DE INDUSTRIALIZACIÓN SUSTITUTIVA DE IMPORTACIONES}

Uno de los pilares de la campaña política que llevó al poder al Frente Popular encabezado por el Presidente Pedro Aguirre Cerda, fue la idea del progreso y de crear una industria que fuese capaz de autoabastecer la demanda interna del país. Sumado a esto y como consecuencia de los devastadores efectos del terremoto que en 1939 afectó gravemente a la zona de Concepción, se crean mediante la Ley 6.634 del 29 de abril de 1939, la Corporación de Reconstrucción y Auxilio (actual Oficina Nacional de Emergencia, ONEMI) y la Corporación de Fomento a la Producción (CORFO). El objetivo de esta última era promover el fortalecimiento de la actividad industrial en Chile y uno de sus proyectos emblemáticos fue la Siderúrgica Huachipato de la Compañía de Aceros del Pacífico (CAP), que fue el resultado de más de 10 años de estudios y gestiones llevadas a cabo por la CORFO para instalarse en la bahía de San Vicente, en Talcahuano ${ }^{33}$.

Entre los años 1940 y 1970 se identifican un conjunto de hitos en la historia urbana de la ciudad, entre los que destacan: productive policies. The aim was to identify the historical events that defined different interventions with significant effects on urban space.

\section{Results}

\section{THE CITY OF PROGRESS: THE BEGINNING OF THE IMPORT-SUBSTITUTION INDUSTRIALIZATION}

One of the pillars of the campaign that brought the Popular Front, led by Pedro Aguirre Cerda, to power was the idea of progress and creation of industries able to self-supply the domestic market. In addition to this, and as a consequence of the 1939 earthquake that struck the area of Concepción, the Corporation for Reconstruction and Relief (renamed National Office of Emergency of the Interior Ministry, ONEMI) and the Production Development Corporation (CORFO) were created by Act 6,634 of April 29, 1939. The mission of the latter agency was to promote the strengthening of industrial activity and one of its most emblematic projects was the Huachipato steel complex, owned by the Pacific Steel Company (CAP); this project was

33 Echeñique, A. y Rodríguez, C. 1990. 
- Las políticas implementadas por CORFO, a fines de los años 40, con el fin de crear un polo productivo industrial en el Gran Concepción.

- La instalación de la Planta Siderúrgica de Huachipato el 25 de noviembre de 1950.

- La vigencia del Plan Regulador Intercomunal de Concepción del año 1962, que establece significativas áreas de expansión urbana, proyectando una superficie construida continua entre Concepción, Talcahuano, Chiguayante y Penco. Cabe subrayar que este Plan condicionó las normativas de los Planos Reguladores comunales respectivos, destacando la definición de espacios para la industria, así como una vocación marcadamente productivista del territorio metropolitano ${ }^{34}$.

En la década de los años 50, por ejemplo, el sector entre Concepción y Talcahuano comienza un rápido poblamiento debido principalmente a la migración de áreas rurales en busca de empleo, como también a la instalación de poblaciones para distintos sectores de trabajadores y directivos de la industria ${ }^{35}$. Por ello es posible pensar que los primeros trabajadores en ocupar los empleos de la naciente industria penquista, al ver la escasa oferta de soluciones habitacionales, se ubicaran en el límite entre Concepción y Talcahuano viendo que

34 Muñoz, F. 2011.

35 Pérez, L. y Salinas, E. 2007. the result of 10 years of studies and initiatives carried out by CORFO to establish in the Bay of San Vicente, Talcahuano ${ }^{33}$.

There are important milestones in the urban history of the city identified between 1940 and 1970 such as:

- Policies implemented by CORFO by the end of the forties aimed at creating an industrial productive center in Greater Concepción.

- The construction of the Huachipato steel complex on November 25, 1950.

- The Intercommunal Master Plan of Concepción, implemented in 1962; this Plan defines important areas for urban expansion, estimating a continuous builtup area between Concepción, Talcahuano, Chiguayante and Penco. It is worth mentioning that this initiative set the guidelines for each respective communal Master Plan, defining spaces for industry and the productive vocation of the metropolitan territory ${ }^{34}$.

During the fifties, the area between Concepcion and Talcahuano experienced a rapid population

33 Echeñique, A. Rodríguez, C. 1990

34 Muñoz F. 2011 
ya en la primera mitad de la década de los 50 surgen las primeras zonas intermedias entre ambas comunas, que surgen como asentamientos irregulares nacidos de "las tomas de sitios"36.

Es así como una de las primeras consecuencias de la instalación de la usina de Huachipato y la masiva llegada de población proveniente desde fuera de la ciudad, fue la construcción de campamentos por parte de la empresa para los trabajadores y sus familias, ubicados entre el alto horno y el sector Arenal, terreno que hoy en día es parte de la industria. Por este motivo, luego de unos años la planta CAP-Huachipato y la CORVI buscaron construir conjuntos de viviendas para satisfacer la creciente necesidad habitacional de los trabajadores, a lo que se suma los efectos del terremoto de 1960, que indudablemente dio una extrema urgencia al encargo. Uno de los más claros ejemplos de esta intervención es la Villa San Pedro, ubicada en lo que en ese entonces era parte de Coronel, "localización seleccionada por su relativa cercanía al centro de Concepción y el precio conveniente de los lotes existentes alli" 37 .

Entre la década de los 60 y 70 es evidente el crecimiento de los centros urbanos de Concepción y Talcahuano, en consecuencia la forma del área urbana de cada ciudad se complejiza, sobre todo

36 Almendras, A. 2009.

37 Franck, S. y Pérez, L. 2009, pág.140. growth due to both the migration from rural areas in search for employment and the establishment of villages for workers and managers from the industrial sector ${ }^{35}$. This is why it is possible to think that the first workers of this nascent industry, given the limited housing supply, settled down in the limit between Concepcion and Talcahuano; the first intermediate areas appeared in the early fifties, these were irregular settlements that emerged from land takeovers ${ }^{36}$.

One of the first consequences of Huachipato and the massive arrival of migrants was the construction of settlements for the workers and their families; this site was located between Alto Horno and Arenal, an area that is now part of the company. For this reason, CAP-Huachipato and the Housing Corporation (CORVI) built housing developments so as to satisfying the housing need of workers; in addition, the 1960 earthquake turn this situation into a matter of urgency. One of the most telling examples of this intervention is San Pedro Village, located in the then territory of Coronel, "location selected because of its closeness to the downtown of Concepción and the favorable price of land ${ }^{37}$."

35 Pérez, L. and Salinas, E. 2007.

36 Almendras, A. 2009.

37 Franck, S. and Pérez, L. 2009, pág.140. 
para la ciudad de Concepción, la cual incorpora en sus límites nuevas áreas ocupando cada vez más espacios, siguiendo las mismas direcciones de expansión del período anterior.

Considerando lo último, los resultados de cada uno de los indicadores correspondientes a este período muestran el siguiente comportamiento:

\section{A) Nivel educacional:}

Los datos, sólo disponibles para los censos de 1952 y 1970, muestran que solamente la comuna de Concepción destaca por concentrar una proporción relevante de población con estudios universitarios (2,8\% y $2,5 \%$ en cada censo). Los valores son muy superiores al resto de las comunas vecinas y por sobre el promedio nacional. En este contexto, destaca que las demás comunas de la conurbación (Talcahuano, Penco y Coronel) mantienen niveles bajos en el período, siendo superados largamente por el promedio nacional en el año 1970. Bajo este contexto, los datos muestran una consolidación de la comuna de Concepción como la que concentra a los grupos de mayor nivel socio-educacional de la naciente conurbación.

En términos gruesos, se puede señalar que las élites de la ciudad se mantienen hasta esta época en el centro de la ciudad, cercanas al centro administrativo.
Between the sixties and seventies the growth of the urban centers of Concepcion and Talcahuano was evident; as a consequence, the form of the urban area of each city got complex, especially in Concepción, which added new areas to its limits thus using more space, repeating the same expansion patterns of the previous period.

Considering the above, the results of each of the indicators for this period show the following behavior:

\section{a) Educational Level:}

This data, only available for the 1952 and 1970 censuses, shows that the municipality of Concepción stands out for concentrating an important proportion of people with undergraduate studies $(2.8 \%$ and $2.5 \%$ on each census.) These figures largely exceed those of the rest of townships, including the national average. In this context, the remaining municipalities of the conurbation (Talcahuano, Penco and Coronel) presented low levels during this period, being surpassed by the national average in 1970. In this context, the data in Table 2 shows the consolidation of Concepcion as the municipality that concentrates the groups 
TABLA 2. PORCENTAJE DE POBLACIÓN CON ESTUDIOS UNIVERSITARIOS POR COMUNA. CENSOS DE 1952 Y 1970

\begin{tabular}{lll} 
Comuna & 1952 & 1970 \\
Talcahuano & 0,8 & 0,7 \\
\hline Concepción & 2,8 & 2,5 \\
\hline Penco & 0,4 & 0,5 \\
\hline Coronel & 0,4 & 0,8 \\
\hline CHILE & 0,3 & 1,3 \\
\hline
\end{tabular}

Fuente: INE 1952 y 1970

TABLA 3: PORCENTAJE DE POBLACIÓN ECONÓMICAMENTE ACTIVA EMPLEADA EN LA INDUSTRIA Y LOS SERVICIOS. CENSOS DE 1940, 1952 Y 1970

\begin{tabular}{|c|c|c|c|c|c|c|}
\hline \multirow[t]{2}{*}{ COMUNA } & \multicolumn{3}{|c|}{$\begin{array}{l}\text { Porcentaje de } \\
\text { PEA ocupada en } \\
\text { Industria }\end{array}$} & \multicolumn{3}{|c|}{$\begin{array}{l}\text { Porcentaje de } \\
\text { PEA ocupada en } \\
\text { Servicios }\end{array}$} \\
\hline & 1940 & 1952 & 1970 & 1940 & 1952 & 1970 \\
\hline Concepción & 34,0 & 32,4 & 20,5 & 19,9 & 31,8 & 33,2 \\
\hline Talcahuano & 14,8 & 25,7 & 26,6 & 39,6 & 44,7 & 26,2 \\
\hline Penco & 31,1 & 37,5 & 15,3 & 6,4 & 9,7 & 16,0 \\
\hline Coronel & 11,0 & 10,8 & 13,8 & 8,2 & 15,0 & 23,3 \\
\hline CHILE & 16,8 & 19,0 & 16,6 & 12,5 & 22,2 & 24,1 \\
\hline
\end{tabular}

Fuente: INE 1940, 1952 y 1970.

42 revista invi № 75 / Agosto 2012 / Volumen N ${ }^{0}$ 27: 21-71
TABLE 2. PERCENTAGE OF THE POPULATION WITH UNDERGRADUATE STUDIES PER MUNICIPALITY. 1952 AND 1970 CENSUSES

\begin{tabular}{lll} 
Municipality & 1952 & 1970 \\
\hline Talcahuano & 0,8 & 0,7 \\
\hline Concepción & 2,8 & 2,5 \\
\hline Penco & 0,4 & 0,5 \\
\hline Coronel & 0,4 & 0,8 \\
\hline CHILE & 0,3 & 1,3 \\
\hline
\end{tabular}

Source: National Institute of Statistics (INE) 1952 and 1970.

TABLE 3. PERCENTAGE OF THE ECONOMICALLY ACTIVE POPULATION ENGAGED IN INDUSTRY AND SERVICES. 1940, 1952 AND 1970 CENSUSES

\begin{tabular}{lllllll} 
Municipality & \multicolumn{2}{l}{$\begin{array}{l}\text { Percentage of EAP } \\
\text { engaged in industry }\end{array}$} & \multicolumn{3}{l}{$\begin{array}{l}\text { Percentage of } \\
\text { EAP engaged in } \\
\text { services }\end{array}$} \\
& 1940 & 1952 & 1970 & 1940 & 1952 & 1970 \\
\hline Concepción & 34,0 & 32,4 & 20,5 & 19,9 & 31,8 & 33,2 \\
\hline Talcahuano & 14,8 & 25,7 & 26,6 & 39,6 & 44,7 & 26,2 \\
\hline Penco & 31,1 & 37,5 & 15,3 & 6,4 & 9,7 & 16,0 \\
\hline Coronel & 11,0 & 10,8 & 13,8 & 8,2 & 15,0 & 23,3 \\
\hline CHILE & 16,8 & 19,0 & 16,6 & 12,5 & 22,2 & 24,1 \\
\hline
\end{tabular}

Source: INE 1940, 1952 and 1970. 


\section{B) Población empleada en actividades industriales y de SERVICIOS}

Como ya se ha mencionado, la actividad industrial en el Gran Concepción ha sido impulsora de muchos de los cambios urbanos ocurridos durante el siglo recién pasado. Los datos de los censos de 1940, 1952 y 1970 muestran una concentración temprana de la Población Económicamente Activa dedicada a la industria en las comunas de Concepción y Penco. Es destacable que en ambas, para el año 1940, cerca de un tercio de su PEA se empleaba en la industria. Del mismo modo destaca la proporción mucho menor del empleo industrial en Talcahuano, que incluso está por debajo del promedio nacional. Posteriormente, en 1952 y 1970 Talcahuano muestra un relevante crecimiento de su empleo industrial, llegando al 26\% de su PEA.

En el mismo período en Concepción, el empleo industrial pierde importancia relativa, aunque se mantiene por sobre el promedio nacional. El descenso del empleo industrial es muy relevante en Penco, que pasa del 37,5\% en 1952 al 15,3\% en 1970.

Bajo este contexto, los datos muestran un traslado del grueso de la población ligada a la industria desde Concepción y sobre todo desde Penco hacia Talcahuano, acorde con una mayor cercanía a las plantas industriales localizadas en esta última comuna. Relevancia cobra el hecho de que en este período el sector de Hualpén, en la comuna

ARTICUL 0: Industrialización desarrollo y ciudad: transformaciones socio-demográficas y espaciales en la geografía social del Gran Concepción (1950-2010)/

Enrique Aliste Almuna, Miguel Contreras Alonso y Valeria Sandoval Manríquez with higher socio-educational level of the then new conurbation.

In broad terms, it is possible to point out that elite groups remained in the downtown of the city, close to the administrative district.

\section{B) Population engaged in industrial and Services ACTIVITIES}

Industrial activity in Greater Concepción has promoted many of the changes that occurred in the past century. Information retrieved from the 1940, 1952 and 1970 censuses shows an early concentration of Economically Active Population (EAP) engaged in industrial activity in Concepción and Penco. By 1940, a third of the EAP belonging to these municipalities was engaged in industry. Likewise, it is worth mentioning the lower proportion of industrial employment in Talcahuano, which was even below the national average. In 1952 and 1970 this city showed an important increase in industrial employment, reaching the $26 \%$ of its EAP.

During the same period Concepcion experienced a decrease in this type of activity, however, it remained above the national average. Furthermore, Penco showed a slump in industrial employment, which dropped from $37.5 \%$ in 1952 to $15.3 \%$ in 1970. See Table 3. 
de Talcahuano, comenzó un proceso de acelerado crecimiento, estrechamente vinculado al escenario de nuevas industrias instaladas en la zona como parte de la estrategia desarrollista implementada desde inicios de la década del 40.

En el caso de los servicios hay que considerar que Concepción y Talcahuano históricamente han sido por un lado centros administrativos y por otro de comercio y transporte, respectivamente, lo que ha contribuido a que estas comunas se sitúen entre los centros de servicios más importantes de Chile. Los datos muestran un significativo crecimiento del empleo en servicios en la comuna de Concepción, a la vez que un crecimiento inicial y luego un brusco decrecimiento del mismo en Talcahuano (del 44,7\% al 26,2\% entre 1952 y 1970). Tanto Penco como Coronel incrementan la proporción de manera constante en esa etapa, pero sin alcanzar los valores de las otras comunas.

El análisis global de los datos tienden a mostrar un comportamiento claro: Concepción pasa de ser una ciudad con predominio de empleo industrial a una con predominio del rubro de servicios en el período; al mismo tiempo, Talcahuano parece mostrar el fenómeno totalmente opuesto, lo que puede llevar a mirar cómo en el seno de la conurbación naciente, comienza a surgir una nueva configuración social de la ciudad con un perfil muy definido: por un lado la industria, por otro los servicios.
In this context, this data shows that most of the population engaged in industrial activities moved from Concepción, and most especially Penco, to Talcahuano due to the closeness to the industrial facilities located in the latter township. During this period, Hualpén, located in Talcahuano, showed a rapid growth closely linked to the emergence of new industries built in the area as part of the development strategy launched in the forties.

As for the services activities, Concepcion and Talcahuano have historically been an administrative center and a transport and trade center respectively, this is why these municipalities are regarded as one of the most important Chilean services centers. The data shows an important increase in services employment in Concepción; likewise, Talcahuano showed an initial growth and a subsequent slump in this area (from $44.7 \%$ to 26.2\% between 1952 and 1970.) Both Penco and Coronel experienced a constant increase in services employment but their figures remained low when compared to other municipalities.

Global analysis of data reveals a clear pattern: Concepción changed from an industrial into a services city over this period; at the same time, Talcahuano seems to experience a completely 


\section{c) Nivel de envejecimiento}

Los antecedentes muestran en general que durante el período 1952 y 1982 (este último tomado como referencia que proyecta la tendencia), todas las comunas presentaron niveles de envejecimiento (proporción de población mayor de 65 años) que se ubicaban por debajo del nivel nacional. En este contexto general, la comuna de Concepción presentaba niveles relativamente más altos, los que fueron creciendo de forma constante en los tres censos considerados. Cabe destacar que Talcahuano en el período mantiene el nivel de envejecimiento más bajo de toda la conurbación, manteniéndose constante entre 1952 y 1970, lo que se asocia a una estructura de alto crecimiento demográfico, rápida expansión urbana y la llegada de población joven atraída por el perfil de empleo allí posible.

La industria, al parecer, siguió atrayendo a población más joven que encontraba en Talcahuano una interesante oportunidad de empleo y con ello, comenzando a hacer eco de las ideas propias del progreso y el desarrollo, en donde las promesas de un futuro con mayores posibilidades a las bondades de un modelo que ofrecía mejores posibilidades de acceso a los bienes y a los servicios, eran posibles a través de un empleo asalariado. Uno de los bienes más sensibles y simbólicos era (y sigue siendo) sin lugar a dudas la vivienda. Ello, paulatinamente irá colaborando a la definición de aquel perfil de ciudad que silenciosamente se va conformando sobre opposite process. This is how a new social configuration, defined by the industry and services activities, emerged within the new conurbation.

\section{c) Ageing Level}

During the 1952 and 1982 period (the latter interval being used as the reference that projects the trend) all municipalities showed ageing levels (proportion of the population over 65 years) below the national average. In this context, Concepción presented relatively high ageing levels, this indicator steadily increased in each census. It is worth noting that Talcahuano had the lowest ageing levels of the conurbation, remaining unchanged between 1952 and 1970; this trend is linked to high urban growth, rapid urban expansion and the arrival of young people attracted by the type of employment available there.

Young people perceived Talcahuano as a job opportunity, attracted by the idea of progress and development in which promises of a future with more access to goods and services was possible through paid employment. One of the most critical and symbolic goods was (and remains so) housing. This fact contributed to the definition of the city character, which was 
TABLA 4. PORCENTAJE DE POBLACIÓN MAYOR DE 65 AÑOS POR COMUNA. CENSOS DE 1952, 1970 Y 1982.

\begin{tabular}{llll} 
Comuna & 1952 & 1970 & 1982 \\
\hline Talcahuano & 2,8 & 2,8 & 3,8 \\
\hline Concepción & 3,3 & 4,1 & 5,1 \\
\hline Penco & 3,0 & 3,5 & 4,8 \\
\hline Coronel & 2,9 & 3,2 & 4,6 \\
\hline CHILE & 4,0 & 5,0 & 5,8 \\
\hline
\end{tabular}

Fuente: INE 1940, 1952 y 1970.

la base de estos cimientos tan relevantes, como la derivada de la llegada de población a causa de la notoria presencia industrial.

La ciudad del progreso muestra entonces diversos signos y crea una serie de símbolos. Se trata de la ciudad que va construyéndose al amparo de esta nueva forma de concebir no sólo la economía sino la vida urbana: la ciudad se convierte en el ícono de una nueva forma de vida. El trabajo asalariado crea nuevos hábitos, nuevas formas de habitar, nuevas posibilidades y nuevas necesidades, entre ellas, la de vivienda. En la ciudad del progreso se asume la condición de estar en construcción, en mutación a partir de transformaciones que emergen, en primer término, del cambio que se comienza a dar en las características sociodemográficas de su población.
TABLE 4. PERCENTAGE OF POPULATION OVER 65 YEARS PER MUNICIPALITY. 1952, 1970 AND 1982

\begin{tabular}{llll} 
Municipality & 1952 & 1970 & 1982 \\
\hline Talcahuano & 2,8 & 2,8 & 3,8 \\
\hline Concepción & 3,3 & 4,1 & 5,1 \\
\hline Penco & 3,0 & 3,5 & 4,8 \\
\hline Coronel & 2,9 & 3,2 & 4,6 \\
\hline CHILE & 4,0 & 5,0 & 5,8 \\
\hline
\end{tabular}

Source: INE 1940, 1952 and 1970.

quietly taking shape on the basis of foundations such as the arrival of population attracted by industrial activity.

Then, the city of progress shows different signs and creates a series of important symbols. This is about a city that grows under a new way of thinking not only of economy, but also of urban life: the city became the icon of a new way of life. Paid employment creates new habits, new ways of living, new opportunities and new needs such as housing. In the city of progress is assumed the condition of being under construction in terms of the transformations that emerged during the first period, it was the beginning of a change within the sociodemographic characteristics of population. 


\section{LA CIUDAD DEL DESARROLLO: ETAPA DE ECONOMÍA ABIERTA}

Durante este período, uno de los más grandes procesos urbanos que queda manifiesto es la consolidación de la conurbación, la cual muestra una clara estructura dual Concepción-Servicios / Talcahuano-Industrial (al que se agrega el rol portuario), asociada a los nodos menores de Penco con su industria cerámica, Lirquén con sus servicios portuarios y Chiguayante y San Pedro como áreas de expansión residencial que de a poco juegan un rol mayor en servicios ${ }^{38}$. Los principales elementos que afectaron la estructura de la ciudad durante la etapa se pueden resumir de la siguiente manera:

- Al inicio del período, el modelo de sustitución de importaciones presentaba signos de crisis, lo que unido a la crisis política implicó, a nivel nacional, la imposición de un modelo de economía abierta que quitaba los elementos proteccionistas a la industria nacional ${ }^{39}$.

- En complemento con el nuevo modelo de desarrollo, en 1979 se aprueba la Política Nacional de Desarrollo Urbano, que establece que el suelo urbano no es un recurso escaso, que además es necesario aplicar sistemas flexibles de planificación, con una mínima intervención estatal y que finalmente hay que eliminar restricciones

38 Núñez, F. 2007.

39 Muñoz, F. 2011

\section{THE CITY OF DEVELOPMENT: THE OPEN ECONOMY STAGE}

The consolidation of the conurbation is one of the largest urban processes that emerged during this period; this process showed a clear dual structure Concepción-Services/TalcahuanoIndustry (including port activities) linked to the minor nodes of Penco-ceramic industry-, Lirquén -port services- and Chiguayante and San Pedro as areas of residential expansion growing in importance in relation to services activities $^{38}$. The main elements that affected the structure of the city during this period can be summarized as follows:

- At the beginning of the period the importsubstitution model was in crisis, this, together with the political crisis, triggered the implementation of an open economy model that left the national industry without protectionist elements ${ }^{39}$.

- Complementing the new development model, the National Policy of Urban Development was enacted in 1979, this initiative established that urban land was not a scarce resource, applied flexible planning systems

\footnotetext{
38 Núñez, F. 2007.
}

39 Muñoz F. 2011. 
y definir procedimientos para permitir el crecimiento natural de las áreas urbanas, siguiendo la tendencia del mercado ${ }^{40}$. Bajo este contexto se aprueba el Plan Regulador Metropolitano de Concepción (1982) y los planes reguladores respectivos, los que muestran una flexibilización en las condiciones de uso de suelo y de construcción ${ }^{41}$.

- Durante la década de los 80 se produjo un boom pesquero; la pesca extractiva se consolidó (sobre todo la pesca pelágica como el jurel) como uno de los pilares de la economía chilena, teniendo al eje Talcahuano-San Vicente como principal polo de atracción de inversiones y a Coronel siguiéndole de cerca ${ }^{42}$.

- El 22 de noviembre de 1990 se decreta la quiebra de Lozapenco S.A., gatillada por la no cancelación de la deuda a los acreedores, el no pago de indemnizaciones por despidos y el atraso en el pago de las cotizaciones previsionales de los trabajadores; esto trajo como consecuencia la pérdida de fuente laboral para miles de trabajadores de la zona ${ }^{43}$.

- A contar de la segunda mitad de la década de los 90, la industria pesquera se vio afectada por una crisis derivada de la menor disponibilidad

$\begin{array}{ll}40 & \text { MINVU. } 2006 . \\ 41 & \text { Muñoz, F. } 2011 . \\ 42 & \text { ASIPES. } 2010 . \\ 43 & \text { Bravo, F. 2004 }\end{array}$

revista invi № 75 / Agosto 2012 / Volumen № 27: 21-71 with minimum state intervention, eliminated restrictions and defined procedures to allow the natural growth of urban areas according to market trends ${ }^{40}$. In this context, the Concepción Master Plan and the respective plans were voted in 1982, as a consequence, the conditions for land use and construction became more flexible $e^{41}$.

- There was a fishing boom in the eighties; extractive fishing (especially the pelagic scad fishing) became one of the pillars of Chilean economy, with Talcahuano-San Vicente, and Coronel on a smaller scale, as a center of attraction for investment ${ }^{42}$.

- Lozapenco S.A. filed for bankruptcy on November 22, 1990 due to non-cancellation of debts and severance packages and delays on the payment of pension contributions; as a result, thousands of people in the area lost their jobs ${ }^{43}$.

- During the second half of the nineties, the fishing industry was affected by the scarcity
40 MINVU. 2006.

41 Muñoz F. 2011

42 ASIPES. 2010.

43 Bravo, F. 2004. 
del recurso jurel y de la carencia de herramientas para el control de las especies marinas a largo plazo.

- Las mejoras en las carreteras en el período cercano al año 2000, fortalecieron la trama sobre la cual se fue extendiendo la ciudad, con sus líneas ferroviarias y de tranvías, y posteriormente con la incorporación de autopistas y carreteras (o "rutas"), generadoras de crecimiento urbano y gatillantes de la conurbación en todos los sentidos: los puentes que han permitido conectar y trasladar crecimientos poblacionales e industriales del centro metropolitano hacia la zona sur y finalmente el plan de transporte Biovías y la ruta inter portuaria ${ }^{44}$.

El significativo avance inmobiliario a fines de la década de los 90, generó una importante y variada oferta habitacional en Concepción, expandiéndose la zona urbana a sectores incluso no incluidos como tales en algunos instrumentos de planificación territorial ${ }^{45}$.

Es importante resaltar que en cada una de las comunas del área de estudio existe o existió alguna actividad industrial, entre las que sobresalen: CCU, Albano, Caprice, Nobis, entre otras en Concepción; Huachipato, Petrox (hoy ENAP Refinerías Biobío), Cementos Biobío y PetroDoweInchalam

44 Pérez, L. y Salinas, E. 2007.

45 Pérez, L. e Hidalgo, R. 2010; Muñoz, 2011.

ARTÍCULO: Industrialización, desarrollo y ciudad: transformaciones socio-demográficas y espaciales en la geografía social del Gran Concepción (1950-2010)/

Enrique Aliste Almuna, Miguel Contreras Alonso y Valeria Sandoval Manríquez of scad and the lack of tools to control marine species in the long-term.

- The improvements in highways circa 2000 strengthened the urban grid over which the city expanded, firstly with rail and tram lines and then with the construction of highways and roads (or "routes"), generating urban growth and defining the conurbation; these are the bridges that connect and mobilize people and industries from the downtown area to the south; it is worth mentioning the Biovias transport plan and the inter-port road $^{44}$.

The significant growth of the real estate market during the nineties gave birth to an important and rich housing supply in Concepcion, expanding the urban area towards sectors that were not included in territorial planning instruments ${ }^{45}$.

It is important to point out that each of the analyzed municipalities experienced, or are still experiencing, industrial activity, such as CCU, Albano, Caprice and Nobis in Concepción; Huachipato, Petrox (known today as Enap Refinerías Bíobío), Cementos Bíobío,

44 Pérez, L. y Salinas, E. 2007

45 Pérez, L. and Hidalgo, R. 2010; Muñoz, 2011. 
en Talcahuano; industria textil como Machasa en Chiguayante; industria papelera (hoy NorskeSkog Biobío) en San Pedro de La Paz, y Compañía Refinería de Azúcar de Viña del Mar (Crav), Vidrios Lirquén (Vipla), la Fábrica Nacional de Loza Fanaloza (posteriormente Lozapenco), COSAF, las minas de carbón de El Refugio, el Puerto de Lirquén, fábricas de calzado, entre otras en Penco.

En términos sociodemográficos, la situación era la que se detalla a continuación:

\section{A) Nivel Socio-Educacional}

Hacia el año 1982 (Figura 2), la población con mayor nivel socio-educacional de la conurbación se mantenía cerca del área central (fundacional) de Concepción. En efecto, los distritos de mayor status corresponden a aquellos localizados cerca de la Plaza Perú y de la Universidad de Concepción. Junto con ello, se distingue el distrito "Lonco", en el camino a Chiguayante, como otro sector de alto nivel socio-educacional.

Este último sector posee características bien cotizadas en cuanto al valor del suelo, tales como estar rodeado de bosques nativos y tener vista al río Bío-Bío; posee además rápido acceso a los centros urbanos cercanos a través de la ruta Chiguayante-Concepción-Talcahuano ${ }^{46}$, lo que elevaría el valor del suelo y por consiguiente concentraría a
Petrodow and Inchalam in Talcahuano; textile industry such as Machasa in Chiguayante; paper industry (today Norske-Skog Bíobio) in San Pedro de la Paz; and Compañía Refinería de Azúcar de Viña del Mar (Crav), Vidrios Lirquén (Vipla), Fábrica Nacional de Loza, Fanaloza (later known as Lozapenco), COSAF, El Refugio coal mine, the Port of Lirquén and shoe factories in Penco.

In sociodemographic terms, the situation was as follows:

\section{a) Socio-educational level}

Figure 2 shows that by 1982, the population with the highest socio-educational level lived in the downtown area of Concepción. Indeed, better-off districts were located around Plaza Perú or Universidad de Concepción. In addition, the "Lonco" district, located in the road to Chiguayante, stands out as another area of high socio-educational level.

This sector presents important assets in relation to land value such as being surrounded by native woodland and the views of Biobio River; likewise, the Chiguayante-ConcepcionTalcahuano road facilitates the access to

46 Pérez, L.y Salinas, E. 2007. 

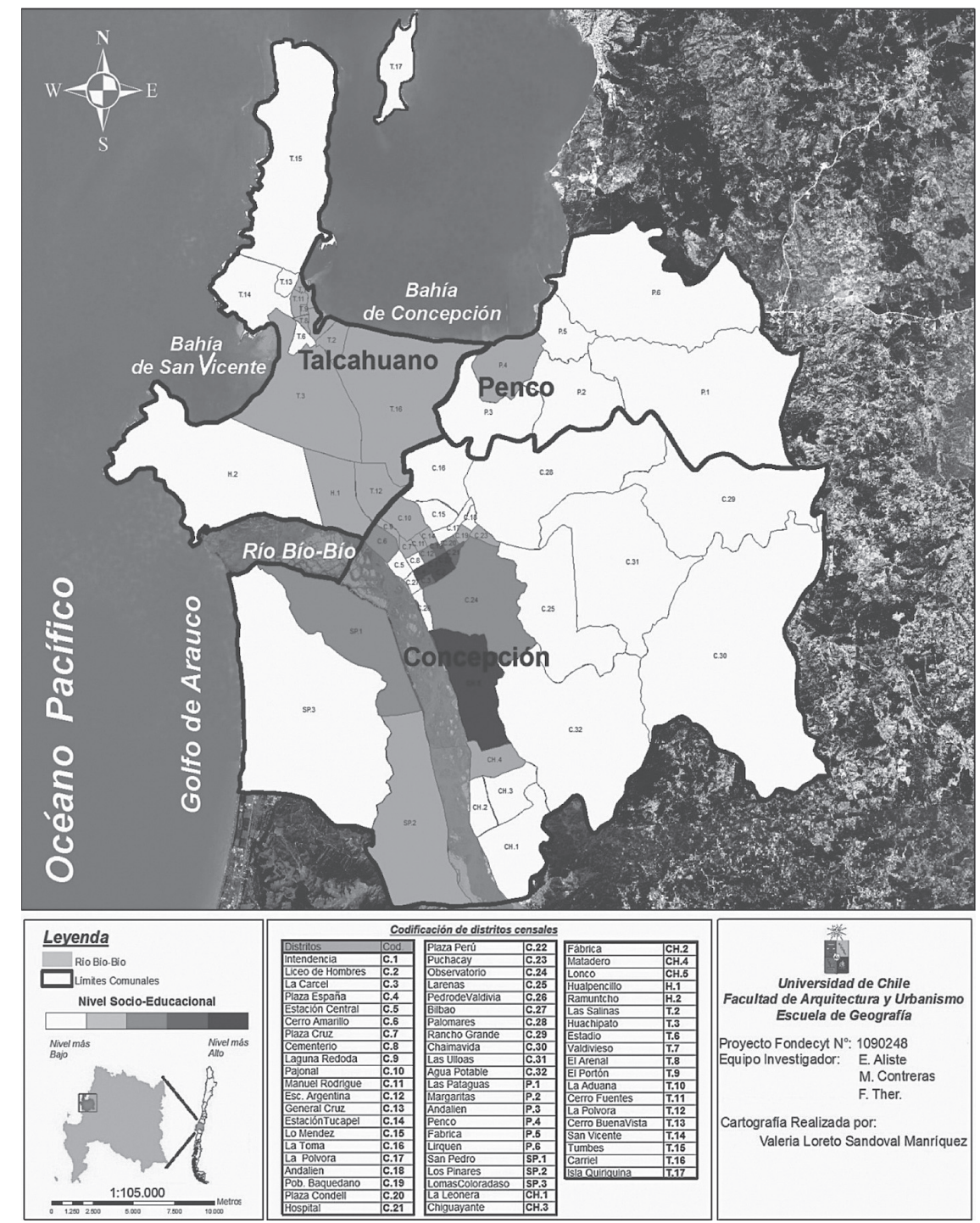

FIGURA 2: DISTRIBUCIÓN POR NIVEL SOCIO-EDUCACIONAL,

AÑO 1982.

FIGURE 2: SOCIO-

EDUCATIONAL DISTRIBUTION, 1982. 
los grupos socio-educacionales más elevados. En contraste con lo anterior, los distritos con menores niveles socio-educacionales correspondían a zonas rurales o áreas urbanas francamente periféricas.

La estructura general de nivel socio-educacional se mantiene para el año 1992, destacando una clara permanencia en la estructura espacial de esta variable. Sin embargo, para el año 2002 (Figura 3) la estructura tiende a ser un poco más compleja, puesto que un distrito de San Pedro, en la otra ribera del río Biobío, comienza a concentrar población de alto status en la misma medida que las zonas centrales de Concepción. Pese a la continuidad de mantener a los grupos de altos ingresos en una zona relativamente central de la conurbación, todas las comunas que componían el área de estudio poseían a lo menos un distrito sobre la media en cuanto al nivel socio-educacional.

Detallando lo anterior, destacan las comunas con distritos que poseen niveles socio-educacionales elevados como Chiguayante en Lonco, San Pedro de la Paz en San Pedro y Los Acacios, los cuales representan sectores acomodados de la ciudad, lo que se relaciona con las diferencias del valor del suelo existentes en el área que, en consecuencia, se traduce en la creciente homogeneidad de los grupos sociales que habitan sectores como estos. nearby urban centers ${ }^{46}$, thus increasing the value of land and concentrating higher socioeducational groups. In contrast, lower socioeducational groups were located in rural or peri-urban areas.

By 1992, the general socio-educational structure remained unchanged, showing the same spatial structure. However, this structure grew in complexity by 2002, when a district in San Pedro, located in the opposite bank of Bíobio River, began to concentrate highstatus groups at the same level as that of the central area of Concepción, as shown in figure 3. Despite gathering high-income groups in a relatively central area of the conurbation, all municipalities had one district above the average as far as the socio-educational level was concerned.

In this sense, districts with high socioeducational levels, such as Chiguayante in Lonco, San Pedro de la Paz in San Pedro and Los Acacios, represent better-off areas of the city; this fact is related to the differences regarding land value and the growing homogeneity of social groups living in these areas.

46 Pérez, L. y Salinas, E. 2007. 


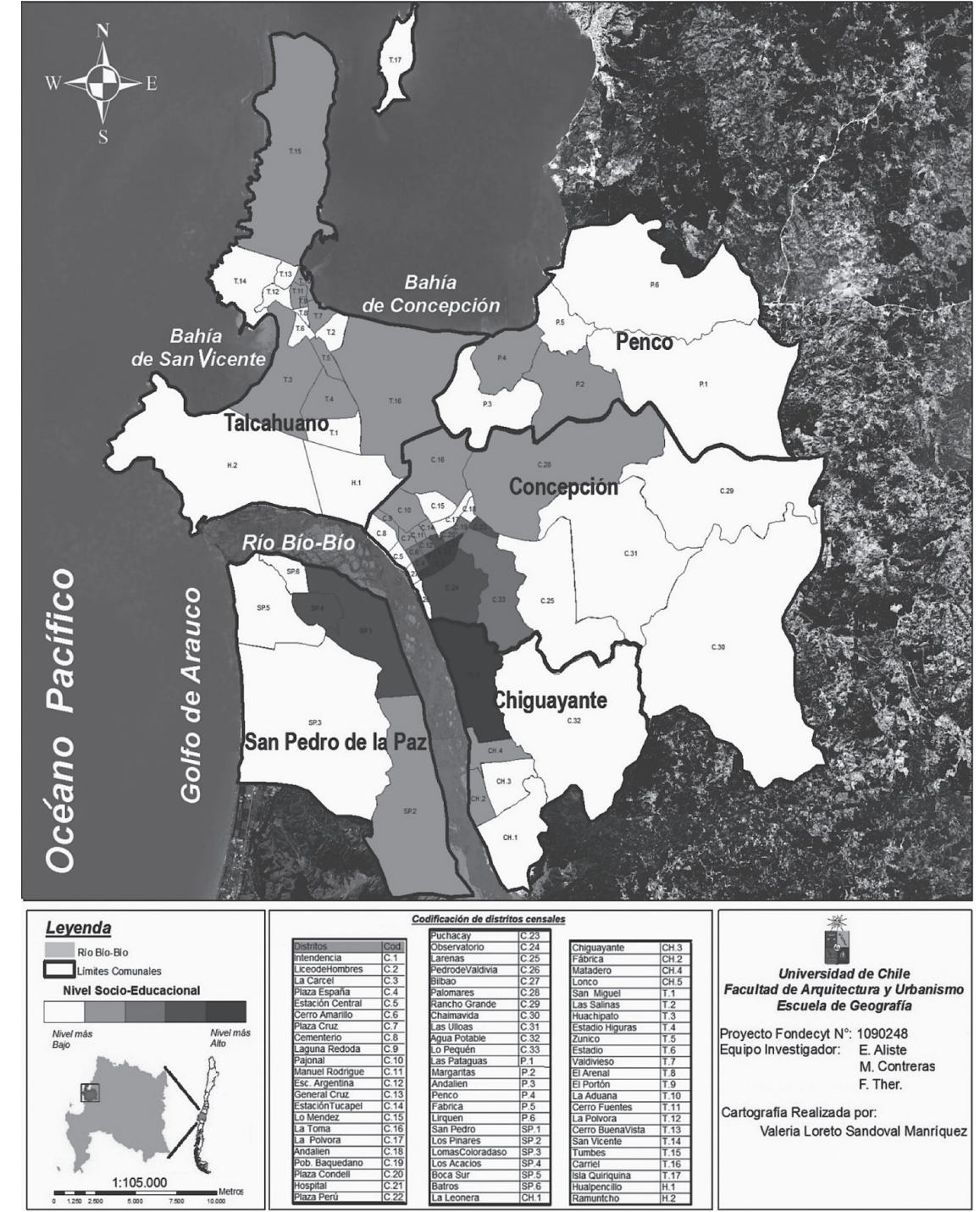

FIGURA 3: DISTRIBUCIÓN POR NIVEL SOCIO-EDUCACIONAL, AÑO 2002.

FIGURE 3. SOCIO-

EDUCATIONAL DISTRIBUTION, 2002 
Pese a estas particularidades, los antecedentes tienden a mostrar una significativa continuidad en la estructura espacial del nivel socio-educacional, a nivel distrital, en el Gran Concepción. En este sentido, al año 2002 no se manifestaban de forma significativa los procesos de traslado de la población de alto status hacia zonas periféricas, o al menos era un proceso incipiente que no quedó registrado en los datos recolectados en dicho censo. Los antecedentes recopilados en terreno indican que durante la primera década del siglo XXI, la ciudad comenzó a presentar urbanizaciones de alto nivel en zonas más periféricas, específicamente a través de barrios cerrados (Lomas de San Andrés, Lomas de San Sebastián y San Pedro, por ejemplo). Queda esperar que este proceso más reciente se manifieste en los datos del próximo censo de 2012.

\section{B) Población empleada en la industria y los Servicios}

Según datos aportados por el INE en el año 1982, cerca del 10\% de la población residente en el área de estudio trabajaba en actividades relacionadas con las diferentes industrias existentes. La Figura 6 muestra que la distribución de la población empleada en actividades industriales es compleja. Aparecen zonas de concentración en el noroeste de la comuna de Concepción, en la zona central de Talcahuano y en Penco. Niveles altos de concentración de trabajadores industriales se presentan en todas las comunas, con una baja presencia en el centro de Concepción, en Lonco y en algunos distritos rurales.
Despite these particularities, data shows a significant continuity of socio-educational spatial structure at district level in Greater Concepción. In this sense, by 2002 there were no significant shifts of better-off population towards peri-urban areas, or at least this was a new process that was not recorded in data collected from this census. Field data indicates that housing estates of high quality, most especially gated communities (Lomas de San Andrés, Lomas de San Sebastián and San Pedro, to name just a few), began to emerge in peri-urban areas during the first decade of the $X X I$ century. The expression of this process in the 2012 census remains to be seen.

\section{B) Population engaged in Industry and Services}

According to data retrieved from INE, 10 percent of the population living in the analyzed area worked in the industrial sector by 1982. Figure 4 shows that there is a complex distribution of population engaged in industry. Likewise, there is an emergence of concentration areas in the north-west of Concepción as well as in the downtown area of Talcahuno and Penco. All municipalities but the center of Concepción, Lonco and some rural districts showed high concentration levels of industrial workers. 

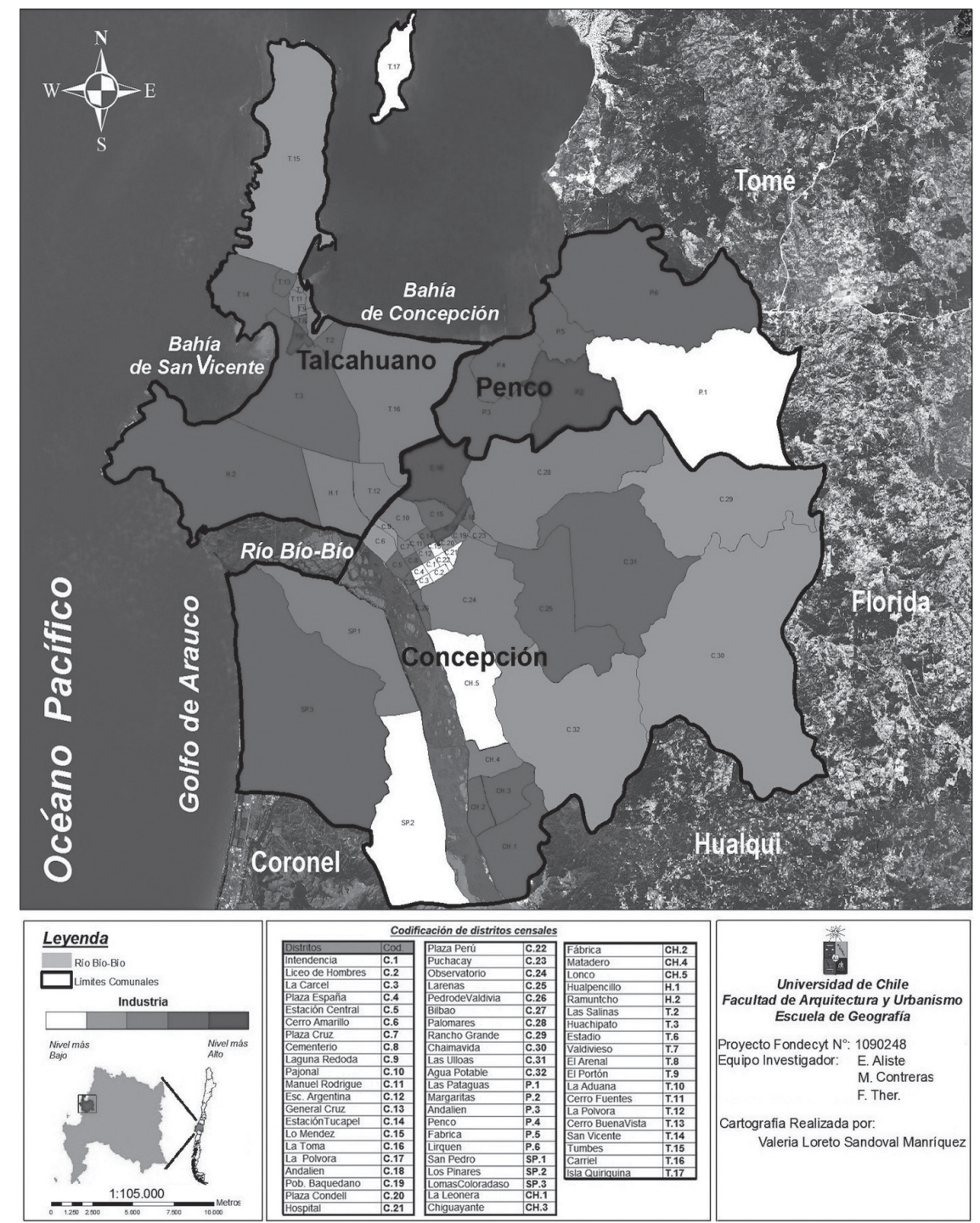

FIGURA 4: DISTRIBUCIÓN PEA SECTOR INDUSTRIAL, 1982.

FIGURE 4: EAP DISTRIBUTION, INDUSTRIAL SECTOR, 1982 
Para el año 1992, el patrón de concentración de los empleados en la industria mantiene su complejidad, manteniendo la concentración al noroeste de Concepción, en Penco, en Talcahuano y sumando un nuevo foco en el extremo sur de Chiguayante. Para el año 2002 (Figura 5) se manifiestan ciertos cambios pues los distritos de Concepción dejan de concentrar población empleada en la industria, toda vez que los valores más altos se concentran definitivamente en Talcahuano (sector Hualpén), San Pedro (Sector La Boca) y Chiguayante (sector oriente de la comuna).

Destaca en todo el período analizado que existe cierta relación espacial inversa entre nivel socioeducacional y proporción de población empleada en actividades industriales.

En relación con los servicios, es destacable que durante los tres censos analizados, también existen patrones de continuidad muy marcados. Resalta la presencia de población ocupada en servicios en toda la conurbación; sin embargo, la concentración de la población empleada en servicios presenta sus mayores valores en la zona central de la comuna de Concepción para los tres períodos. Sin perjuicio de lo anterior, los resultados del censo de 1992 y 2002 tienden a mostrar que el patrón espacial de esta variable parece seguir la distribución del indicador de nivel socio-educacional, pues se presentan valores altos en los sectores de Lonco y San Pedro.
By 1992, the concentration pattern of industrial workers remained complex in the north-west of Concepción, Penco and Talcahuano; the far south of Chiguayante was also added to this structure. By 2002, the districts of Concepción stopped concentrating people engaged in industry as they began to definitely establish in Talcahuano (Hualpén), San Pedro (La Boca) and Chiguayante (western area), as Figure 5 shows.

It is worth noting that during this period there was a sort of inverse spatial relationship between the socio-educational level and the proportion of people engaged in industry.

In relation to services, it is worth mentioning the presence of clear continuity patterns recorded in the three analyzed censuses. The presence of population engaged in services across the conurbation appears as an important factor; however, the concentration of people working in the services sector focused in downtown Concepcion during the three periods. Notwithstanding, the results of the 1992 and 2002 censuses show that the spatial pattern of this variable goes along the distribution of socio-educational levels, which were high in Lonco and San Pedro. 


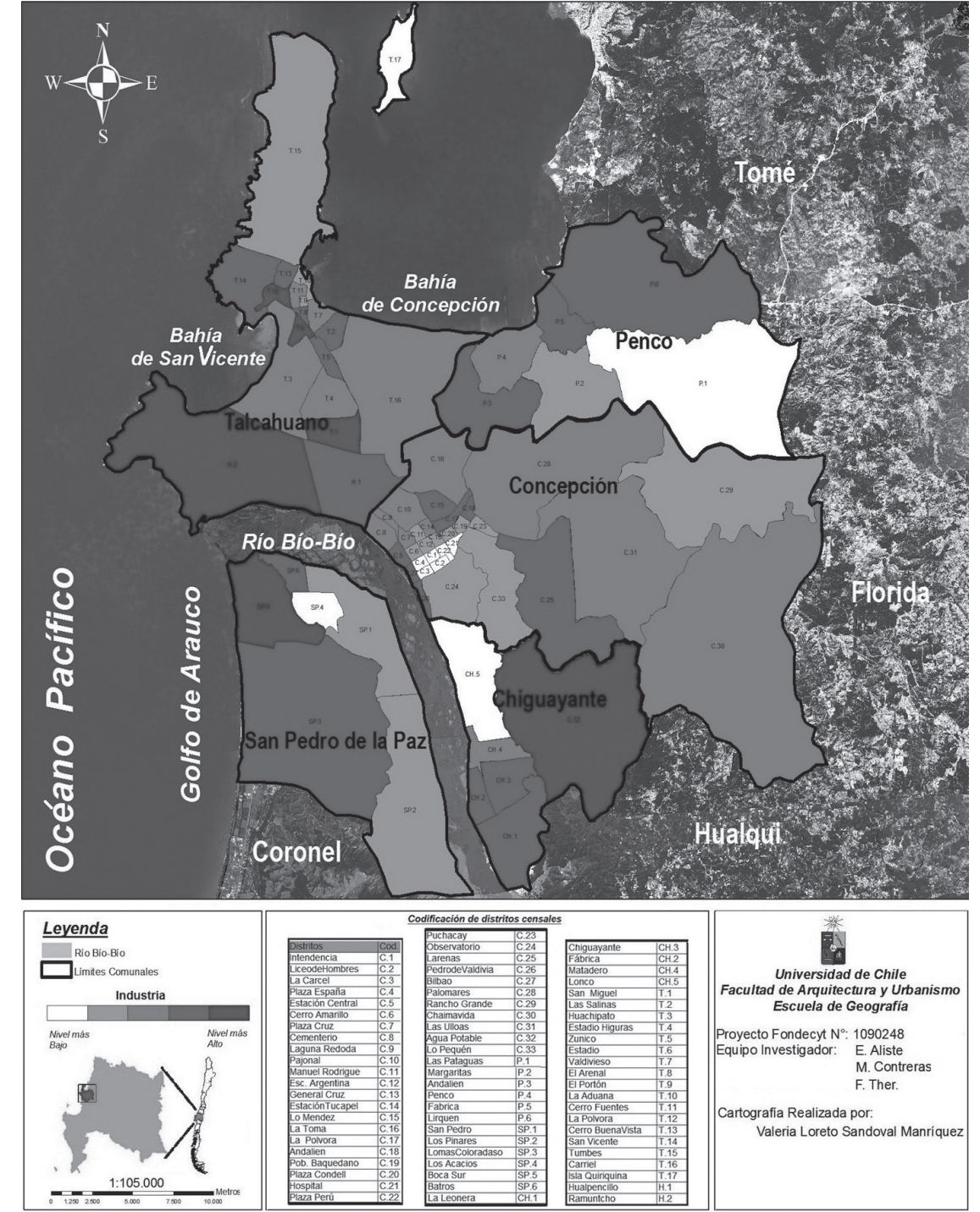

FIGURA 5: DISTRIBUCIÓN PEA, SECTOR INDUSTRIAL, 2002.

FIGURE 5: EAP DISTRIBUTION, INDUSTRIAL SECTOR, 2002

ARTíCULO: Industrialización, desarrollo y ciudad: transformaciones socio-demográficas y 


\section{c) Envejecimiento de LA POBlación}

Al dar una mirada general a los resultados de los tres últimos censos, se puede observar que en todos los casos la mayor cantidad de distritos con población en esta condición se concentra específicamente en el centro de Concepción (Intendencia, Liceo de Hombres, Laguna Redonda, Plaza Perú). Por otro lado, también se debe notar que el distrito que destaca por poseer el nivel más bajo en este indicador es "Isla Quiriquina" (Península de Tumbes) explicado por la presencia de la Base de la Armada.

El comportamiento general muestra que la conurbación tiende a seguir los procesos de envejecimiento demográfico asociados al país y a otras zonas metropolitanas: incremento general de la población de mayor edad y concentración relativa de ésta en las zonas urbanas centrales, más cercanas de los servicios.

En general, salvo un par de excepciones, la distribución de los distritos que proporcionalmente poseen mayor cantidad de personas que superan los 65 años coinciden, especialmente en el centro, con aquellos de nivel socio educacional más alto.

La ciudad del desarrollo, más allá de seguir experimentando un período de transformación (que es permanente), tiende paulatinamente a acentuar un proceso de segregación espacial en donde ciertos barrios comienzan a consolidarse conforme con atributos sociodemográficos como los aquí revisados: las categorías socio-educacionales con mayores niveles de preparación se tienden a concentrar

\section{c) Population ageing}

From a broad view of the last three censuses results, it is observed that ageing population focuses in the downtown area of Concepción (Intendencia, Liceo de Hombres, Laguna Redonda, Plaza Perú). On the other hand, Isla Quintana (Tumbes Peninsula) showed the lowest ageing level due to the presence of the Navy Base.

The overall behavior shows that the conurbation tends to follow the demographic ageing processes experienced by the country and other metropolitan areas: a general increase in elderly population and concentration of this group in central urban areas, which are closer to services.

In general terms, with the exception of a couple of cases, the distribution of districts that proportionately have more population older than 65 years matches those of higher socioeducational level.

The city of development, more than experiencing a (permanent) transformation process, tends to gradually accentuate a spatial segregation process in which certain neighborhoods began to consolidate according to sociodemographic features: socio-educational categories with 
en ciertos barrios que no coinciden con aquellos en donde comienzan a vivir los trabajadores de la industria. Al mismo tiempo, esta condición empieza a configurar una ciudad que se expande, que busca nuevos sitios para los nuevos asentamientos. Pero otro proceso muy relevante comienza a emerger, y es el surgimiento del sector servicios como el principal y cada vez más distante en relación a la industria en lo que respecta a la población económicamente activa.

La ciudad del desarrollo se comienza a distanciar de la industria, empieza a acoger los servicios y sigue el patrón de envejecimiento especialmente en las zonas centrales. Lo anterior nos lleva a repensar las connotaciones o aspectos que comienzan a quedar contenidos en esta noción de desarrollo. Esto es, suele mirarse la condición de desarrollo especialmente en lo que concierne a sus aspectos materiales. Desde esta perspectiva, este período concentra probablemente los mayores incrementos en obras de infraestructura, especialmente vial y de transportes $^{47}$. Lo mismo se ve en los nuevos proyectos inmobiliarios y las inversiones que desde el punto de vista de su visibilidad, comienzan a cambiar el rostro de la ciudad: aparecen los mall, nuevas urbanizaciones en sectores cercanos al aeropuerto Carriel Sur, mayor infraestructura educacional. No obstante, es también el período en que la ciudad acentúa paulatinamente diferencias entre sus habitantes

47 Pérez, L. y Salinas, E. 2007. higher levels of education tend to concentrate on certain neighborhoods that do not match those in which industrial workers live. At the same time, this condition configures a city on expansion, a city that looks for new areas for the new settlements. However, there was another important process that emerged, which was the rise of the services sector as the main and more distant activity in relation to industry as far as economically active population was concerned.

The city of development began to distance from industry, provided accommodation for services and followed the ageing pattern, especially in central areas. This leads to rethink of those aspects contained within the development concept. In other words, development is generally seen from a material perspective. In this context, this period probably concentrates the main increase in infrastructure, especially in road and transport areas ${ }^{47}$. In addition, new building projects and investments changed the aspect of the city in terms of visibility: there was an emergence of shopping malls, housing estates in areas next to Carriel Sur airport and more educational infrastructure. However, this period also witnessed a gradual increase in the

47 Pérez, L. and Salinas, E. 2007. 
no sólo en su perfil sociodemográfico como acá se ha visto, sino también en términos de ingresos, del lugar en donde habitan y de vulnerabilidad ${ }^{48}$.

Son estos signos de la ciudad los que permiten poner en discusión la noción de desarrollo y su correlato espacial en el tiempo. Si bien es cierto que hay importantes cambios que han favorecido a la población en general, como los incrementos en el PIB, el acceso a servicios básicos, las mejoras en la nutrición, mayor cobertura de educación y salud, entre muchos otros elementos que comparados con la realidad de los años '50 marcan indudables mejoras, también es cierto que el devenir de la ciudad y el modo de habitarla no parece haber tenido una mejora si se piensa en aspectos como la sustentabilidad o las formas de ocupación que garanticen y proyecten las mejoras en la calidad de vida. Después de todo, los sucesos del 27 de febrero de 2010 dejaron en evidencia que los sectores más afectados fueron precisamente aquellos que junto con ser más vulnerables desde el punto de vista de exposición a zonas de riesgo natural, eran también zonas con importante vulnerabilidad social. differences among people regarding not only sociodemographic, but also income, place of living and vulnerability aspects ${ }^{48}$.

These signs allow the discussion on the development concept and its spatial correlate over time. While there have been important changes in favor of the population such as the increase in GDP, access to basic services, improvements in terms of nutrition, education and health among other elements that compared to the fifties constitute a definite step forward, the future of the city and the way of inhabiting it do not represent progress when thinking about sustainability or occupation that ensure improvements regarding quality of life. After all, the events occurred on February 27,2010 , revealed that the most affected sectors were those that, apart from being vulnerable in relation to the exposure to natural risks, presented important social vulnerability. 


\section{Discusión y conclusiones}

\section{ELEMENTOS DE CONTINUIDAD Y CAMBIO EN LA ESTRUCTURA SOCIO-ESPACIAL DE LA CONURBACIÓN}

Los datos referidos a nivel socio-educacional tienden a cambiar hacia el año 2002, cuando aparecen indicios de un traslado de los grupos de mayor estatus hacia la zona de San Pedro de la Paz, sin ser una localización evidentemente periférica. El principal elemento de cambio en este caso, corresponde a la trayectoria de la comuna de Concepción como lugar de residencia de empleados de la industria. En todo el período, la comuna perdió relevancia en concentrar trabajadores vinculados al rubro industrial que hasta el año 1992 aún se mantenían en algunos distritos; sin embargo, ya en el año 2002 la comuna había perdido este carácter casi por completo.

Ello no debiera extrañar si se considera que las transformaciones propias, ocurridas con posterioridad a los años '80, implicaron una serie de transformaciones en la base económica y en la estructura de la economía regional. La emergencia de los sectores pesquero industrial y forestal comienza a tomar peso, pero no en Concepción sino en Talcahuano y en comunas del interior de la región. Por otra parte, la puesta en marcha del modelo neoliberal aplicado incluso a los suelos urbanos, tiene entre sus consecuencias este cambio en los

ARTÍCULO: Industrialización, desarrollo y ciudad: transformaciones socio-demográficas y espaciales en la geografía social del Gran Concepción (1950-2010)/

Enrique Aliste Almuna, Miguel Contreras Alonso y Valeria Sandoval Manríquez

\section{Discussion and conclusions}

\author{
CONTINUITY AND CHANGE ELEMENTS WITHIN \\ THE SOCIO-SPATIAL STRUCTURE OF THE \\ CONURBATION:
}

By 2002, data regarding socio-educational level tended to change when higher-status groups shifted towards San Pedro de la Paz, a non-peripheral area. In this case, the main element of change was the municipality of Concepción as the residence of industrial workers. During this period, this township lost relevance when it came to concentrating people engaged in industry, who by 1992 still lived in some districts; however, this municipality had almost completely lost its industrial character by 2002 .

It is not surprising, then, that transformations after the eighties implied a series of changes within the economic base and the structure of regional economy. The emergence of fishing and forestry industries became relevant in Talcahuano and other municipalities located within the region. On the other hand, the application of the neoliberal model had consequences such as the change in the 
patrones de ocupación de las áreas urbanas. Ello conlleva un proceso de reorganización espacial.

A su vez, Talcahuano, una comuna inicialmente de servicios, concentra trabajadores industriales desde 1952 y mantiene este carácter hasta la actualidad, traspasando este rol a Hualpén que recientemente ha pasado a convertirse en comuna, entre otras razones, por su importante incremento demográfico derivado de la industria de Talcahuano.

En este sentido, pese a que algunos autores sostienen que existen roles definidos para cada una de las comunas del Gran Concepción, una de las características que acentúan la estructura del sistema es la diversidad funcional de cada comuna en sí misma ${ }^{49}$. Es posible constatar funciones industriales incluso en comunas marcadamente residenciales como San Pedro de la Paz y Chiguayante e incluso el mismo Concepción.

Sin embargo, en el contexto del tema en estudio, es vital hacer notar que la estructura demográfica, en tanto reflejo de una vocación o sello de la ciudad en torno a su perfil industrial, ha mostrado variaciones importantes que hablan de una transferencia de población que otorgan a algunas comunas cierta impronta, más allá de la existencia o no de actividad industrial en ellas. Así, claramente Concepción ya no sería una comuna industrial, Talcahuano se ve más industrial que portuaria, y pese a

49 Baeriswyl, S. 2007. revista invi № 75 / Agosto 2012 / Volumen N N 27: 21-71 occupation pattern of urban areas. This situation led to spatial reorganization.

In addition, Talcahuano, which initially was a municipality focused on services, began to concentrate industrial workers from 1952, creating a character that remains today; this role was transferred to Hualpén, an area that was recently declared municipality due to its demographic growth derived from the industrial activity of Talcahuano.

In this sense, despite the fact that some authors state that there are defined roles for each of the municipalities in Greater Concepcion, one of the main characteristics that stress the structure of the system is the functional diversity of each township ${ }^{49}$. Then, it is possible to verify industrial activity in residential municipalities such as San Pedro de la Paz, Chiguayante and even Concepción.

However, in the context of this research, it is worth noting that the demographic structure, as the expression of a vocation or character of a city built around industry, has shown important variations related to population shifts that leave distinctive marks disregarding the presence of

49 Baeriswyl. S. 2007. 
tener industrias, las comunas de San Pedro de La Paz y Chiguayante son claramente residenciales.

Los datos expuestos permiten sugerir algunos caminos importantes desde el punto de vista analítico. Entre ellos, pareciera ser relevante el hecho de que la ciudad que contiene el Gran Concepción, como conglomerado metropolitano, se compone de varias ciudades al mismo tiempo y en diferentes tiempos. Ello es, desde el punto de vista conceptual, la esencia de un territorio: mutar y ser reflejo de su dinámica social en el tiempo. No obstante, cuando se busca avanzar en la geografía social de la ciudad, aproximarse a entender su estructura y la forma como cambia en el tiempo, no puede depender sólo de la mirada sociodemográfica. Vemos acá que ello no es suficiente no sólo porque los datos son una muestra parcial de la realidad territorial, sino porque además hay una serie de otros elementos menos visibles pero probablemente tanto o más importantes que van aparejados a los datos de las estadísticas sociodemográficas: el curso de las decisiones estratégicas sobre la ciudad van ocurriendo al amparo de ciertas prácticas discursivas, como por ejemplo, aquellas que acompañan los planes de desarrollo, los planes reguladores comunales e intercomunales, por señalar algunos.

El análisis espacial de las variables e indicadores analizados, muestra sin embargo una interesante relación espacial entre nivel socioeconómico, proporción de población empleada en servicios y población mayor de 65 años. Esta relación es coherente

ARTÍCULO: Industrialización, desarrollo y ciudad: transformaciones socio-demográficas y espaciales en la geografía social del Gran Concepción (1950-2010)/

Enrique Aliste Almuna, Miguel Contreras Alonso y Valeria Sandoval Manríquez industrial activity. In this way, Concepción is no longer an industrial municipality and Talcahuano is more a manufacturing than a port area and despite having industries, San Pedro de la Paz and Chiguayante are clearly residential municipalities.

Available data suggests important considerations from an analytical point of view. It appears to be relevant the fact that the city that contains Greater Concepcion, as a large metropolitan conglomerate, is different cities at the same time and in different times. From a conceptual point of view, this is the essence of a territory: to change and being the expression of its social dynamics over time. However, when it comes to analyzing the social geography of the city, understanding its structure and how it changes over time do not depend only on sociodemographic approaches. In this case this is not enough, not only because data offers a limited picture of reality, but also because there are a series of less visible but even more important elements that go along sociodemographic statistics: the course of strategic decisions on the city are subject to discursive practices such as those related to development plans or communal and intercommunal master plans, to name just a few. 
con situaciones de similar comportamiento en estudios realizados en otras ciudades del país como es el caso de Valdivia, Osorno y Puerto Montt ${ }^{50}$. Por otra parte, la variable que se presenta con una relación espacial en un sentido inverso corresponde a la proporción de población ocupada en la industria.

En este contexto, es necesario destacar la alta complejidad de los patrones de distribución de las variables dentro del espacio urbano del Gran Concepción, que no parecen relacionarse con otras áreas metropolitanas. Junto con ello, el análisis de los datos recopilados no logra dar cuenta de acelerados procesos que se viven actualmente en la conurbación, tales como suburbanización, crecimiento vertical, ocupación de áreas de riesgo y de valor ambiental, los que de todas formas fueron detectados en terreno. Estudios posteriores deberán analizar los cambios que ocurren y que pueden alterar los elementos de continuidad identificados hasta el 2002 y que podrían dar cuenta de una nueva etapa en el desarrollo de la ciudad.

\section{LA GEOGRAFÍA SOCIAL DEL GRAN CONCEPCIÓN: UNA MIRADA REFLEXIVA AL PROCESO DE HACER CIUDAD FRENTE AL DISCURSO DEL DESARROLLO}

Los antecedentes sociodemográficos muestran una parcialidad de lo que puede avanzarse en la geografía social de la ciudad. Desde ellos es posible

50 Contreras, M. 2009.

64 revista invi № 75 / Agosto 2012 / Volumen $N^{0}$ 27: 21-71
The spatial analysis of variables and indicators shows an interesting spatial relationship among socioeconomic level, proportion of people engaged in services activities and population older than 65 years. This relationship is consistent with similar situations recorded in other Chilean cities such as Valdivia, Osorno and Puerto Montt ${ }^{50}$. Additionally, the variable that presents an inverse relationship is the proportion of people engaged in industrial activities.

In this context, it is important to point out the complexity of the distribution patterns of variables within the urban space of Greater Concepción as they do not seem to be related to other metropolitan areas. Moreover, the analysis of collected field data does not account for current processes that are being experienced in the conurbation such as suburbanization, vertical growth and occupation of risk and environmentally-valued areas; these phenomena were detected on the field research. Subsequent research should analyze changes that may alter the continuity elements detected until 2002, thus probably revealing a new stage within the development of the city.

50 Contreras, M. 2009 
referirse, como se ha hecho, a la morfología socioespacial y de un modo descriptivo, sugerir ciertos derroteros en la conformación de la ciudad. Sin embargo, es preciso comprender que los antecedentes logrados en el presente análisis, sólo adquieren un sentido más amplio al colaborar con la exploración de hacer ciudad desde las estrategias, planes y discursos en pro de una idea de desarrollo. Por ello, mirar los discursos del desarrollo, de la ciudad, del progreso y de las formas mediante las cuales la ciudad va articulando sus maneras de ir configurándose paulatinamente, conforme con la dinámica propia que le va dando sentido con el paso del tiempo, requiere de algunos antecedentes básicos que ayuden a entender los pasos que se van dando a este respecto.

Los datos revisados nos van mostrando esa ciudad móvil, esa ciudad que va mutando su perfil en virtud de sus cambios en las características de su población, que en rigor, es la base de la ciudad. Mirar a la ciudad como una idea estática es a nuestro juicio un error que conviene discutir en perspectiva. No se trata de eliminar ni vocaciones, ni sellos, ni improntas propias de las ciudades, sino más bien, aceptar que paso a paso las ciudades, como fiel reflejo del estado de la sociedad, van generando respuestas a las maneras de llevar a cabo y poner en práctica ciertos discursos que determinan, a la larga también, algunas formas de concebir su hábitat residencial. Es por ello que al determinar los cambios que sufre esta estructura demográfica, las formas como

\section{SOCIAL GEOGRAPHY OF GREATER CONCEPCIÓN: REFLECTIONS ON THE CITY MAKING PROCESS AGAINST THE DEVELOPMENT DISCOURSE}

Sociodemographic data shows part of the progress that can be achieved in relation to the social geography of the city. It is possible to refer to socio-spatial morphology and descriptively suggest the evolution of the shaping processes of the city. However, it is important to understand that the information offered in this paper acquire a broader sense when combined with city making analysis in relation to strategies, plans and discourses in favor of development. This is why observing development, city and progress discourses, as well as the ways in which the city articulates itself according to the dynamics that give meaning to it over time, requires basic information to understand the evolution of this process.

Analyzed data shows a mobile city that is changing according to the transformations in the characteristics of its population, which strictly speaking is the base of the city. From our point of view, observing the city as a static idea is an error that should be discussed. This is not about eliminating vocations, seals or distinctive marks of cities; rather, accepting that cities, as an expression of the state of society, generate 
se re-articula y re-organiza el espacio social urbano a partir de cambios en los patrones de producción, en las decisiones de los instrumentos y en definitiva, del lugar que demarcará la relación espacial entre lugar de residencia y lugar de trabajo, creará una condición de habitar el espacio que se volcará a abrir una exploración ya no sólo sobre las características habitacionales, sino también sobre los desplazamientos, los tiempos de viaje, las actividades complementarias y el rol que en dicho aspecto cumplirá la ciudad en un sentido amplio y más transversal en el habitar urbano. La idea es que se pueda entender la ciudad más allá de su condición material y ver, a partir de testimonios como el aquí ofrecido, que hay en cada una de estas transformaciones intensidades y elementos que van transformando también el sentido de la ciudad en cada momento histórico. Los discursos del desarrollo son parte de ello, como lo son también las vocaciones productivas, los planes diseñados, las estrategias, etc.

En este caso, la puesta en práctica de grandes discursos como el desarrollista clásico de mediados del siglo XX, que es fruto de economías más abiertas (neoliberal) post años '80, van generando respuestas de la ciudad, no sólo en su morfología y estructura sociodemográfica, también lo hacen respecto de la idea que se construye sobre ellas y es interesante contrastarlo con los datos. En este caso, tenemos los datos que nos permiten mirar lo sucedido con esta capa de la geografía social de la ciudad. Esta capa que nos muestra lo que sucede responses to discourses that determine different ways to understand residential habitat. This is why determining the transformations within the demographic structure of the city, as well as the way this entity organizes the urban space from changes in production patterns, decisions of instruments and the area that defines the spatial relationship between residence and workplace, creates a condition of inhabiting that enables the analysis of mobility, travel times, complementary activities and the role of the city within urban inhabiting. The idea is to understand the city beyond its material condition and observe what lies behind each transformation, intensity and element that changes the evolution of the city at each historical point of time. Development discourses are part of this process, so are productive vocations, plans, strategies, etc.

In this case, the set in motion of large discourses such as the development one, which emerged during the second half of the $20^{\text {th }}$ century and the one that was the result of opening up to markets (neoliberalization) post eighties, generate responses from the city; not only at morphological and sociodemographic levels, but also in what regards to the idea built around them. In this case, data allows the 
con su población, con su localización y la respuesta que socio-demográficamente podemos ver espacialmente. Esta mirada de la geografía social nos ayuda además a ver que algunas ideas que se tienen respecto del Gran Concepción, no son del todo como se creen.

De todas formas, los cambios más fuertes de la última década, con nuevas urbanizaciones, nuevos procesos migratorios intraurbanos, y el mismo efecto del terremoto del 27 de febrero de 2010, sólo puede inferirse como relevante a partir del trabajo de terreno, pero que metodológicamente sólo será posible corroborar próximamente, una vez conocidos los resultados del Censo Nacional de Población y Vivienda del año 2012, en contraste con las observaciones y recopilaciones realizadas en terreno.

En consecuencia y a modo de corolario, al menos dos ciudades se pueden ver en el tiempo a partir de este estudio. Una primera que hemos llamado la ciudad del progreso, caracterizada por ser parte y fiel reflejo de las grandes transformaciones derivadas de la puesta en práctica del discurso desarrollista propio de mediados del siglo XX, con notables transformaciones demográficas como la creciente presencia de población dedicada a trabajar en la industria, una población que se mantiene con bajas tasas de envejecimiento y que va comenzando todo un proceso de reordenamiento interno que va poniendo sello a cada comuna. Asimismo, es la ciudad que ve en la industria el gran símbolo

ARTÍCULO: Industrialización, desarrollo y ciudad: transformaciones socio-demográficas y espaciales en la geografía social del Gran Concepción (1950-2010) /

Enrique Aliste Almuna, Miguel Contreras Alonso y Valeria Sandoval Manríquez analysis of this layer of social geography of the city. Such a layer shows what it is going on with the population, their localization and the sociodemographic response. This approach to social geography is also useful to understand that some ideas regarding Greater Concepción are not as true as they seem to be.

However, major changes occurred during the last decade such as new housing estates, new intra-urban migration processes and the effect of the February 27, 2010 earthquake, are relevant in the fieldwork, but they need to be methodologically corroborated in the 2012 census.

As a corollary, at least two cities can be analyzed over time in this paper: the first one is referred to as the city of progress, characterized for being the reflection of major transformations derived from the set in motion of the development discourse during the second half of the 20th century; these transformations included remarkable demographic changes such as the increase in people engaged in industrial activities, a population that maintains low ageing rates and the beginning of an internal rearranging process that gives each city their own character. Likewise, this is the city that regards industry as the symbol of process and

revista invi № 75 / August 2012 / Volume № 27: 21-71 
de este progreso y en donde surge el nuevo tema de la vivienda como el gran anhelo y necesidad de la ciudad naciente.

La otra ciudad es la del desarrollo, que comienza a consolidarse con el paso de las décadas y que llegada a los años '80, como fruto de grandes transformaciones políticas, sociales y económicas, empieza a sufrir una importante transformación de su base económica y al mismo tiempo, un reordenamiento de la forma en que su población ocupa el espacio. Hay importantes transformaciones en la geografía social que se venía articulando desde la década de los '50, con la acentuación de algunas diferencias, con concentraciones de ciertos segmentos de la población en lugares más definidos dentro de la ciudad, distinguiendo atributos o sellos en cada comuna, aunque no sean exclusivos. La ciudad se va volviendo más lejana a la industria y más cercana a los servicios. El territorio se construye sobre ciertas diferenciaciones importantes. El desarrollo se comienza a sentir también y ya no sólo en los avances y logros materiales; ahora también llegan las externalidades negativas y con ello, los síntomas inesperados del desarrollo, que se manifiestan en la contaminación de aguas y aire fundamentalmente.

La ciudad del progreso promete un futuro glorioso; la ciudad del desarrollo, en cambio, parece dar cuenta de las dificultades no declaradas de los costos del progreso. Los cambios sociodemográficos sólo son una muestra dentro de esta complejidad. the space where housing emerges as a longedfor dream and the need of the new city.

The second city is the city of development; this is one that gained consolidation over decades, being the eighties the span of time that witnessed an important economic transformation and rearrangement of population as the result of political, social and economic changes. There are important transformations in the social geography that was born during the fifties, setting differences that included the concentration of certain population segments in defined areas within the city, emerging the characteristics or marks on each municipality, even if they are not exclusive. The city began to separate from industry and got closer to services. The territory is built over certain relevant distinctions. Development became evident not only in relation to breakthroughs and material achievements, but also in negative externalities and the unexpected symptoms of development such as water and air pollution.

The city of progress promises a glorious future; conversely, the city of development reveals the unseen difficulties of progress. In this line, sociodemographic changes are just a sample within this complexity. 


\section{Bibliografía}

ALISTE, Enrique. Territorio y huellas territoriales: una memoria del espacio vivido en el Gran Concepción, Chile. Desenvolvimento e Meio Ambiente. (23): 25-38, enero 2011. ISSN: 1518-952X.

ALISTE, Enrique y ALMENDRAS, Angie. Trayectoria territorial de la conurbación Concepción-Talcahuano: industria, asentamientos humanos y expresión espacial del desarrollo, 1950-2000. En: PÉREZ, Leonel e HIDALGO, Rodrigo. Concepción Metropolitano. Evolución y desafíos. Santiago, Chile, Universidad de Concepción. 2010. p. 123-149. ISBN 978-956-14-1165-4

ALMENDRAS, Angie. Expansión urbana, cambios de uso del suelo y transformaciones espaciales en la conurbación Concepción - Talcahuano, análisis desde el año 1950 al 2006. Memoria para optar al título profesional de Geógrafa. Santiago, Chile, Facultad de Arquitectura y Urbanismo, Universidad de Chile. 2009. 130 p.

ASIPES. Inicios de la industria pesquera. Los 80 y el boom pesquero. [En línea]. Asociación de Industriales Pesqueros. [Fecha de consulta en marzo de 2010]. Disponible en http://www.asipes.cl/QuienesSomos.aspx?Me_Id $=4$.

AZÓCAR, Gerardo; SANHUEZA, Rodrigo y HENRÍQUEZ, Cristián. Cambio en los patrones de crecimiento en una ciudad intermedia: el caso de Chillán en Chile Central. [En línea]. EURE. 29(87): 79-92, septiembre 2003. ISSN 0250-7161. Disponible en: http:// dx.doi.org/10.4067/S0250-71612003008700006.

ARTÍCULO: Industrialización, desarrollo y ciudad: transformaciones socio-demográficas y espaciales en la geografía social del Gran Concepción (1950-2010)

Enrique Aliste Almuna, Miguel Contreras Alonso y Valeria Sandoval Manríquez
BAERISWYL, Sergio. Crecimiento urbano del Gran Concepción, patrones y tendencias de una metropolización en Chile. En: HIDALGO, Rodrigo, Mattos, Carlos de y Arenas, Federico. Chile: del país urbano al país metropolitano. Santiago, Chile, Ediciones Pontificia Universidad Católica de Chile. 2009. p. 241-255. ISBN 978-956-1410-541.

BRAUDEL, Fernand. Les ambitions de l'Histoire. Paris, Francia, Éditions de Fallois. 1997. 663 p. ISBN 10: 2253904627.

BRAV0, Fernando. Caso Lozapenco S.A. [En línea]. Facultad de Economía y Negocios, Universidad de Chile. 2004. [Fecha de consulta en enero de 2010]. Disponible en http://hdl.handle.net/2250/2459.

CONTRERAS, Miguel. Análisis de la estructura socioterritorial de la ciudad de Valdivia, efectos de la globalización en una ciudad intermedia del sistema urbano chileno. Tesis para optar al grado de Magíster en Geografía. Santiago, Chile, Facultad de Arquitectura y Urbanismo, Universidad de Chile (inédita). 2009. 139 p.

DI MÉO, Guy. Géographie sociale et territoire. Paris, Francia, Nathan. 1998

DI MÉO, Guy y BULÉON, Pascal. L'espace social. Paris, Francia, Armand Colin. 2005.

ECHEÑIQUE, Antonia y RODRÍGUEZ, Concepción. Historia de la Compañía de Aceros del Pacífico S. A. Huachipato: consolidación del proceso siderúrgico chileno, 1905 - 1950. Santiago, Chile, CAP S. A. de Inversiones. 1990. 191 p. 
FONT, Antonio. Anatomía de una metrópoli discontinua: la Barcelona Metropolitana. Papers Región Metropolitana de Barcelona. (26): 9-19, 1997.

FRANCK, Stéphane y PÉREZ, Leonel. Más que una suma de casas. La Unidad Vecinal Villa San Pedro de Coronel. [En línea]. Revista INVI. 24(67): 127-152, noviembre 2009. ISSN 07188358. Disponible en: http://dx.doi.org/10.4067/ S0718-83582009000300005.

GÓMEZ MENDOZA, Josefina. Geografía e historia. Encuentros y desencuentros en Francia y en España a lo largo del Siglo XX. En: COHEN, Arón y PEINADO, Rafael. Historia, historiografía y ciencias sociales. Granada, España. Ediciones de la Universidad de Granada. 2007. p. 101-147. ISBN 8433846280 .

GORE Bío-Bío. Atlas de los territorios de planificación de la región del Bío-Bío. Concepción, Chile, Observatorio Territorial GORE Bío-Bío. 2005.

GÓNGORA, MARIO. Ensayo histórico sobre la noción de Estado en Chile en los siglos XIX y XX. Santiago, Chile, Editorial La Ciudad. 1981. 149 p.

GUEVARA, Javier. Metodología de investigación para la caracterización de corredores urbanos. [En línea]. Psicología para América Latina. (10), 2007. Disponible en: http://pepsic.bvsalud.org/scielo. php?script=sci_arttext $\&$ pid $=S 1870-350 \times 200700$ 0200010\&lng=pt\&nrm=iso\&tlng=es.

HERNÁNDEZ, Hilario. El Gran Concepción: desarrollo histórico y estructura urbana. Informaciones Geográficas. (30): 47-70, 1983. ISSN 0716-0364.
HIERNAUX, Daniel y LINDON, Alicia. Tratado de geografía humana. México, Anthropos. 652 p. ISBN 84-7658-794-5.

ILABACA, Pedro. Condiciones naturales y crecimiento urbano: caso comuna de Talcahuano. Revista Geográfica de Chile Terra Australis. (40): 7-29, 1995. ISSN 0378-8482.

INE (Chile). Censos Nacionales de Población y Vivienda. Santiago, Chile, Instituto Nacional de Estadísticas. 1940, 1952, 1970, 1982, 1992 y 2002.

INE (Chile). Atlas INE. Santiago, Chile, Instituto Nacional de Estadísticas. 2007

MARDONES, María y VIDAL, Claudia. La zonificación y evaluación de los riesgos naturales de tipo geomorfológico: un instrumento para la planificación urbana en la ciudad de Concepción. [En línea]. EURE. 27(81): 97-122, septiembre 2001. ISSN 0250-7161. Disponible en: http://dx.doi. org/10.4067/S0250-71612001008100006.

MATTOS, Carlos de. (2002). Transformación de las ciudades latinoamericanas: ¿Impactos de la globalización? [En línea]. EURE. 28(85): 5-10, diciembre 2002. ISSN 0250-7161. Disponible en: http:// dx.doi.org/10.4067/S0250-71612002008500001.

MAZZEI, Leonardo y PACHECO, Arnoldo. Historia del traslado de la ciudad de Concepción. Concepción, Chile, Ediciones de la Universidad de Concepción. 1985.

MINVU (Chile). Historia del Ministerio de Vivienda y Urbanismo. [En línea] Ministerio de Vivienda y Urbanismo. 2006. [Fecha de consulta: 13 de abril de 
2010]. Disponible en http://www.minvu.cl/opensite_20061113164636.aspx.

MUÑOZ, Francisco. Instrumentos de planificación territorial del área metropolitana de Concepción y su relación con los modelos de desarrollo 19602011. Memoria para optar al título profesional de Geógrafo. Santiago, Chile, Facultad de Arquitectura y Urbanismo, Universidad de Chile (inédita). 2011. $123 \mathrm{p}$

NÚÑEZ, Francisco. Especificación y estimación de modelos de formación de precios del suelo urbano en el Gran Concepción. Concepción, Chile, Ediciones Facultad de Arquitectura, Universidad del Bío-Bío. 2007.

PACHECO, Arnoldo. Historia de Concepción Siglo XX. Concepción, Chile, Ilustre Municipalidad de Concepción, Ediciones Universidad de Concepción. 1997.

PÉREZ, Leonel e HIDALGO, Rodrigo. Concepción metropolitano. Evolución y desafíos. Santiago, Chile, Editorial Universidad de Concepción. 2010. 318 p. ISBN 978-956-14-1165-4.

PÉREZ, Leonel y SALINAS, Edison. Crecimiento urbano y globalización: transformaciones del Área Metropolitana de Concepción, Chile, 1992-2002. [En línea] Scripta Nova, Revista Electrónica de Geografía y Ciencias Sociales. 11(251), noviembre de 2007. ISSN 1138-9788. Disponible en http:// www.ub.edu/geocrit/sn/sn-251.htm.
ROJAS QUEZADA, Carolina Alejandra; MUÑIZ OLIVERA, Iván y GARCIA LOPEZ, Miguel Angel. Estructura urbana y policentrismo en el Área Metropolitana de Concepción. [En línea]. EURE. 35(105): 47-70, agosto 2009. ISSN 02507161. Disponible en http://dx.doi.org/10.4067/ S0250-71612009000200003.

SMITH, Pamela y ROMERO, Hugo. Efectos del crecimiento urbano del Área Metropolitana de Concepción sobre los humedales de Rocuant-Andalién, Los Batros y Lenga. [En línea]. Revista de geografía Norte Grande. (43): 81-93, septiembre 2009. ISSN 0718-3402. Disponible en http://dx.doi. org/10.4067/S0718-34022009000200005.

SOJA, Edward. History: Geography: Modernity. En: During, Simon, ed. Cultural studies reader. London, Routledge. 2nd ed, 1999. ISBN 0-415-13753-5.

TURM0, Joaquín y MORALES, Carlos. Chile. De la industrialización mediante sustitución de importaciones a la liberalización y diversificación comercial. Boletín Económico de ICE. (2914), 2007.

VAN AUSDAL, Shawn. Medio siglo de geografía histórica en Norte América. Historia Crítica. (32): 198 234, 2006. ISSN 0121-1617. 